$\mathrm{H}-11$ ), 7.32 (d, $1, J=7 \mathrm{~Hz}, \mathrm{H}-9$ ), 7.47 (d, $1, J=7 \mathrm{~Hz}, \mathrm{H}-12$ ), 7.58 (s, 1, H-17); exact mass, $m / e 394.1890$ (calcd for $\mathrm{C}_{23} \mathrm{H}_{26} \mathrm{O}_{4} \mathrm{~N}_{2} m / e$ 394.1891).

Acknowledgment. D.S. thanks the Fulbright Commission for a travel award. Y.-J.S. and E.W. are indebted to the Public Health Service for support of the work in La
Jolla. E.W. expresses his sincere thanks to Professor Dr. Wolfgang Kraus (Institut für Chemie, Universität Hohenheim) and his associates for their hospitality during his sabbatical quarter in Stuttgart in the spring of 1987 and to the Alexander von Humboldt-Stiftung for the award of a Humboldt-Preis in support of his sojourn in Germany.

\title{
"tert-Amino Effect" in Heterocyclic Synthesis. The Effect of a p-Quinone Moiety on the [1,6] H-Transfer and 1,5-Electrocyclization Reactions
}

\author{
Eric O. M. Orlemans, ${ }^{\dagger}$ Ben H. M. Lammerink, ${ }^{\dagger}$ Frank C. J. M. van Veggel, ${ }^{\dagger}$ Willem Verboom, \\ Sybolt Harkema, ${ }^{\ddagger}$ and David N. Reinhoudt* ${ }^{* \dagger}$ \\ University of Twente, 7500 AE Enschede, The Netherlands
}

Received December 18, 1987

\begin{abstract}
(Dialkylamino)benzoquinone 15 and (dialkylamino)naphthoquinones 32 and 34-37 undergo a thermal cyclization to the corresponding pyrrolo[1,2-a]indoles 41,43 , and $45-47$ and to the pyrido[1,2-a]indole 44, respectively. A corresponding hydroquinone, viz. $(E / Z)$-2,5-dimethoxy- $\alpha$-(phenylmethylene)-3,6-di(1-pyrrolidinyl)benzeneacetonitrile (18), cyclizes only slowly to pyrrolo[1,2-a]indole 42. The naphthohydroquinones 38-40 do not undergo a thermal rearrangement. The results demonstrate the accelerating effect of the quinone function on the rate of the reaction, as a result of stabilization of the "negative end" of the intermediate 1,5-dipole. The presence of an electron-donating group at the $\beta$-carbon atom of the vinyl moiety lowers the rate of the reaction. Moreover, this influence is demonstrated by oxidation of one of the sulfur atoms in $\mathbf{3 5}$ to the ketene dithioacetal $S$-monooxide 36, which undergoes a fast thermal isomerization to 47 . Cyclization of the pyrrolidinylnaphthoquinones 32,34 , and 35 yielded exclusively products in which $\mathrm{H}-11 \mathrm{a}$ and $\mathrm{CN}$ have a trans relationship, while in the case of piperidinylnaphthoquinone 37 predominantly trans- $1 H$-benzo[f]pyrido[1,2-a]indole 44a was formed. The trans stereochemistry of $\mathbf{4 3}$ was determined by single-crystal X-ray analysis. Heating of (dialkylamino)naphthoquinone $\mathbf{3 3}$ afforded the indoline $\mathbf{5 0}$ in low yield.
\end{abstract}

\section{Introduction}

In our studies on the "tert-amino effect" in heterocyclic chemistry ${ }^{1,2}$ we have shown that 1-(1-pyrrolidinyl)-2vinylbenzene derivatives 1 (Chart I) rearrange thermally to 2,3,9,9a-tetrahydro- $1 H$-pyrrolo[1,2-a] indoles $2 .^{3}$ This isomerization proceeds via two consecutive pericyclic reactions, viz. a $[1,6]$ hydrogen transfer to give the 1,5-dipole 3 which undergoes a concerted 1,5-dipolar cyclization. ${ }^{4} \mathrm{~A}$ prerequisite for this thermal isomerization is the stabilization of the negative charge in the 1,5-dipole 3 by an electron-withdrawing group (EWG). Furthermore, we have demonstrated the effect of both the substituent $R$ and of different dialkylamino groups on the $[1,6]$ hydrogen transfer and subsequent 1,5-electrocyclization. ${ }^{5}$ Intermediates related to 3 in the formation of pyrrolo[1,2-a]indoles have been postulated by several other groups. ${ }^{6,7}$

The main reason for our current interest in the tertamino effect is the possible application in the synthesis of isomitosanes, ${ }^{8}$ analogues of the antitumor antibiotic mitomycin $C .^{5,9,10}$ In mitomycin $C$ the basic skeleton contains a p-quinone function and therefore we have studied the influence of this oxidation state of 1-(1. pyrrolidinyl)-2-vinylbenzene derivatives on the rate of the thermal cyclization.

Previously, we reported the formation of the Michael adduct 4 in the reaction of 5,5-dimethyl-3-(1pyrrolidinyl)-2-cyclohexen-1-one and dimethyl acetylenedicarboxylate (DMAD). ${ }^{11}$ However, 4 could not be isomerized thermally into the corresponding pyrrolizine. ${ }^{12}$ This lack of reactivity might be attributed to the less reactive

\footnotetext{
† Laboratory of Organic Chemistry.

₹ Laboratory of Chemical Physics.
}

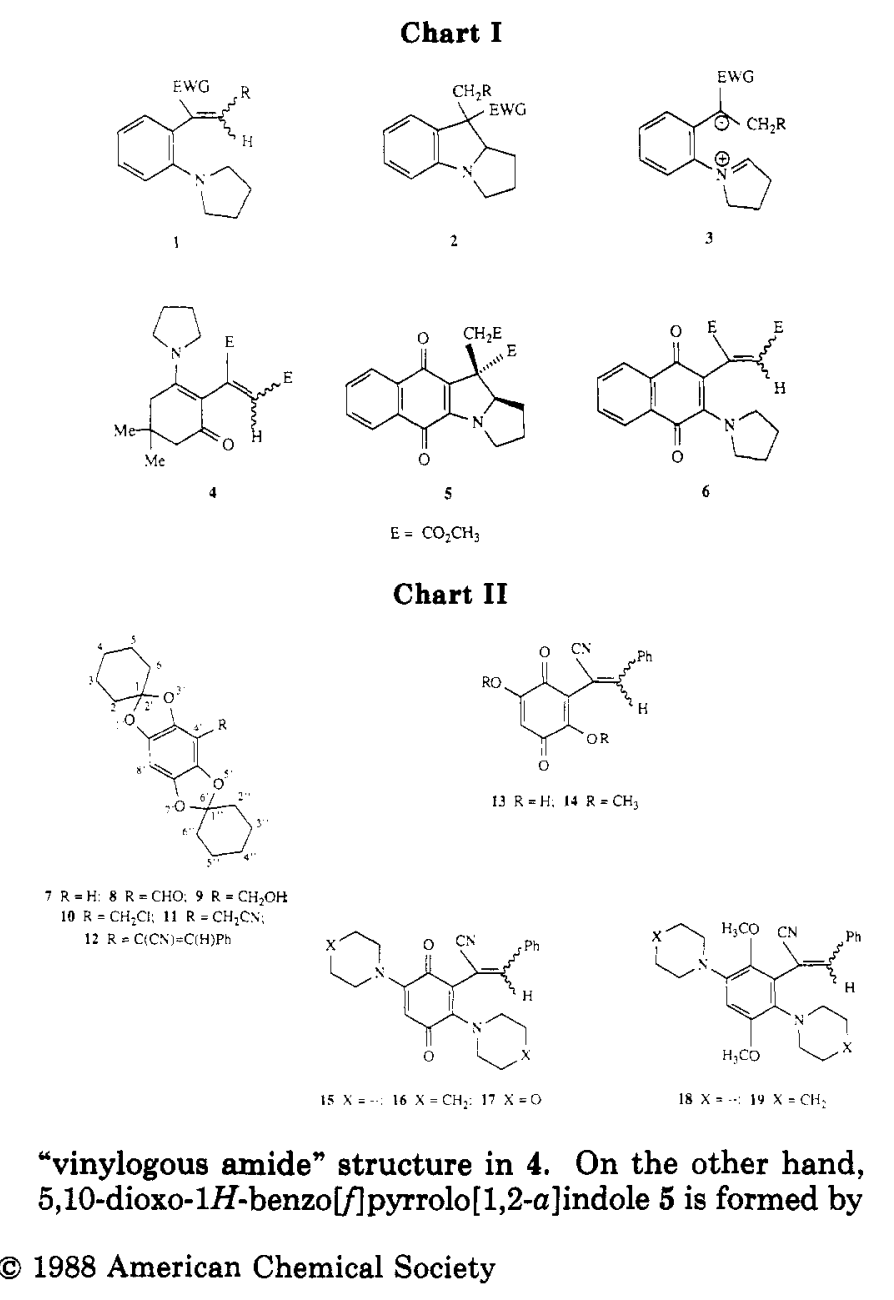

Chart I

Chart II
= $=\mathrm{H}: 8 \mathrm{R}=\mathrm{CHO}: 9 \mathrm{R}=\mathrm{CH}_{2} \mathrm{OH}$ $\mathrm{R}=\mathrm{CH}_{2} \mathrm{Cl}, 11 \mathrm{R}=\mathrm{CH}_{3} \mathrm{C}$

"vinylogous amide" structure in 4. On the other hand, 5,10 -dioxo- $1 H$-benzo[f]pyrrolo[1,2-a]indole 5 is formed by 
a reaction of 2-(1-pyrrolidinyl)-1,4-naphthoquinone with DMAD in 1-butanol at $70^{\circ} \mathrm{C}$, most likely via the Michael adduct $6 .^{9}$ Since in 6 the nitrogen lone pair also constitutes part of a vinylogous amide system we decided to investigate the influence of both a benzo- and a naphthoquinone system on the rate of the 1,5-dipolar cyclization more systematically. This paper describes the synthesis and the thermal isomerization of $p$-quinones containing different $N, N$-dialkylamino groups and different electron-donating substituents at the $\beta$-carbon atom of the vinyl moiety.

\section{Results}

Synthesis of Starting Materials. The starting (dialkylamino) benzoquinones 15-17 were prepared in several steps from the known bisketal $7 . .^{13}$ Monolithiation of $7,13,14$ using $n$-butyllithium ( $n$-BuLi), followed by quenching of the anion with $N, N$-dimethylformamide (DMF) gave the monoformylated product 8 in a good yield (Chart II). Upon reduction with sodium borohydride $\left(\mathrm{NaBH}_{4}\right)$ the resulting benzyl alcohol $9^{15}$ was converted into the corresponding benzyl chloride 10 , under essentially neutral conditions, by refluxing 9 in carbon tetrachloride in the presence of excess of tri- $n$-butylphosphine $\left[(n-\mathrm{Bu})_{3} \mathrm{P}\right] .^{16}$ Conversion of 10 into the corresponding benzyl cyanide 11 was accomplished by refluxing 10 in the presence of potassium cyanide (KCN) and 18-crown-6 in acetonitrile. Finally, the $\alpha$-phenylmethylene group was introduced by condensation of the benzyl cyanide 11 with benzaldehyde in methanol with sodium methoxide as a base. During this reaction one isomer precipitated and after prolonged ${ }^{17}$ reaction this isomer could be isolated in a yield of $77 \%$; in addition a mixture of $E / Z$ isomers was obtained as an oil in a yield of $8 \%$. The stereochemistry of the isomers has not been determined, because it is not relevant for

(1) For other recent applications of the "tert-amino effect", see: (a) Verboom, W.; van Dijk, B. K.; Reinhoudt, D. N. Tetrahedron Lett. 1983, 24, 3923. (b) Verboom, W.; Hamzink, M. R. J.; Reinhoudt, D. N.; Visser, R. Tetrahedron Lett. 1984, 25, 4309. (c) Nijhuis, W. H. N.; Verboom, W. Reinhoudt, D. N.; Harkema, S. J. Am. Chem. Soc. 1987, 109, 3136. (d) Nijhuis, W. H. N.; Verboom, W.; Reinhoudt, D. N. Synthesis 1987, 641.

(2) Meth-Cohn, O.; Suschitzky, H. Adv. Heterocycl. Chem. 1972, 14, 211

(3) Verboom, W.; Reinhoudt, D. N.; Visser, R.; Harkema, S. J. Org. Chem. 1984, 49, 269 .

(4) Reinhoudt, D. N.; Visser, G. W.; Verboom, W.; Benders, P. H.; Pennings, M. L. M. J. Am. Chem. Soc. 1983, 105, 4775.

(5) Dijksman, W. C.; Verboom, W.; Egberink, R. J. M.; Reinhoudt, D. N. J. Org. Chem. 1985, 50, 3791.

(6) (a) Akiba, M.; Kosugi, Y.; Okuyama, M.; Takada, T. J. Org. Chem. 1978, 43, 181. (b) Akiba, M.; Ikuta, S.; Takada, T. J. Chem. Soc., Chem. Commun. 1983, 817. (c) Dijkink, J.; Zonjee, J. N.; de Jong, B. S.; Speckamp, W. N. Heterocycles $1983,20,1255$.

(7) (a) Falling, S. N.; Rapoport, H. J. Org. Chem. 1980, 45, 1260. (b) Luly, J. R.; Rapoport, H. J. Org. Chem. 1982, 47, 2404.

(8) Orlemans, E. O. M.; Verboom, W.; Reinhoudt, D. N. Heterocycles 1986, $24,2797$.

(9) Geevers, J.; Visser, G. W.; Reinhoudt, D. N. Recl. Trav. Chim. Pays-Bas 1979, 98, 251.

(10) (a) Previously we could not introduce a $p$-quinone function in 6,7-substituted tetrahydropyrrolo[1,2- $a$ ] indoles by oxidation.10b Therefore the required quinone moiety must be introduced in an earlier stage of the synthesis. (b) Verboom, W.; Lammerink, B. H. M.; Egberink, R. J. M.; Reinhoudt, D. N.; Harkema, S. J. Org. Chem. 1985, 50, 3797.

(11) Verboom, W.; Visser, G. W.; Trompenaars, W. P.; Reinhoudt, D. N.; Harkema, S.; van Hummel, G. J. Tetrahedron 1981, 37, 3525.

(12) Unpublished results.

(13) Boeckman, J.; Schill, G. Chem. Ber. 1977, 110, 763.

(14) Weider, P. R.; Hegedus, L. S.; Asada, H.; D'Andreq, S. V. J. Org. Chem. 1985, 50, 4276 .

(15) When we tried to prepare the tosylate of 9 using tosyl chloride and triethylamine in dichloromethane, we obtained the benzyl chloride 10 in a yield of $49 \%$. We assume that the initially formed tosylate is substituted by the chloride ion produced.

(16) Hooz, J.; Gilani, S. S. H. Can. J. Chem. 1968, 46, 86.

(17) After $4 \mathrm{~h}$ the reaction was complete and the precipitated isomer could be obtained in a yield of $57 \%$, while in addition a mixture of $E / Z$ isomers was isolated as an oil in a yield of $28 \%$.

Chart III

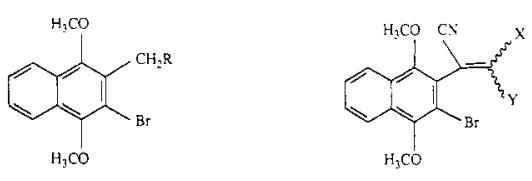

$20 \mathrm{R} \approx \mathrm{Br}, 21 \mathrm{R}=\mathrm{CN}$

X.Y: 22 H. Ph: 23 H. OH; 24 H, OTOS

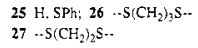

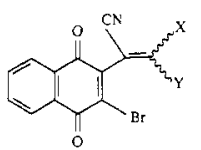

X,Y: 28 H. Ph: 29 H, SPh: $\left.30-\mathrm{S}^{2} \mathrm{CH}_{2}\right)_{3} \mathrm{~S}$ $31+. . \mathrm{S}_{(\mathrm{CH}} \mathrm{CH}_{2} \mathrm{~S}-$

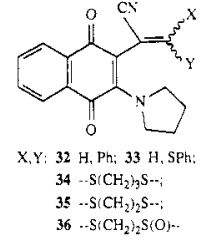

\section{Chart IV}
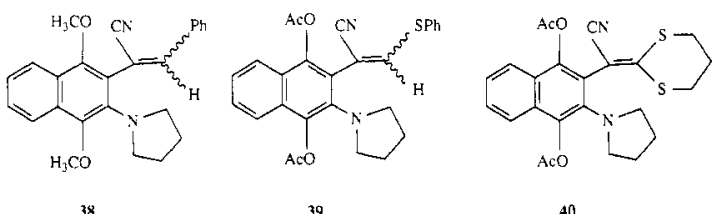

further reaction. Treatment of 12 with boron tribromide $\left(\mathrm{BBr}_{3}\right)$ in dichloromethane resulted in deketalization. Oxidation of the resulting tetrahydroxybenzene derivative with air, followed by methylation of the intermediate dihydroxy quinone 13 using diazomethane produced the dimethoxy quinone 14 in an overall yield of $55 \% .{ }^{18-21}$ Compound 14 was obtained as a mixture of $E / Z$ isomers, as was demonstrated among others by a signal for $=\mathrm{CHPh}$ at $\delta 6.99$ (minor isomer) in the ${ }^{1} \mathrm{H}$ NMR spectrum, while that of the major isomer overlapped with the multiplet for $=\mathrm{C}(\mathrm{H}) \mathrm{Ph} H$ at $\delta 7.9-7.1$. The dimethoxy quinone 14 is a suitable starting material for further conversion into amino quinones. Treatment of 14 with an excess of the appropriate amine in methanol afforded the disubstituted amino quinones 15-17 in excellent yields. With piperidine and morpholine mixtures of $E / Z$ isomers were obtained; these were not separated. The reaction of 14 with pyrrolidine also afforded a mixture of $E / Z$ isomers, from which a single isomer partially precipitated. The structures of the (dialkylamino) benzoquinones 15-17 were proven among others by ${ }^{1} \mathrm{H}$ and ${ }^{13} \mathrm{C}$ NMR spectroscopy. The ${ }^{1} \mathrm{H}$ NMR spectrum of one isomer of 15 showed two pyrrolidinyl moieties, i.e. signals at $\delta 4.2-3.0\left(\mathrm{~m}, 8 \mathrm{H}, \mathrm{NCH}_{2}\right)$ and 2.1-1.7 $\left(\mathrm{m}, 8 \mathrm{H}, \mathrm{CH}_{2}\right)$, in addition to singlets at $\delta 6.74[=\mathrm{CH}(\mathrm{Ph})]$ and $5.32(\mathrm{H}-4)$. The spectra of 16 and 17 were very similar.

15 was converted by reductive methylation, ${ }^{7 a}$ i.e. via catalytic hydrogenation in the presence of dimethyl sulfate and $\mathrm{Ba}(\mathrm{OH})_{2} \cdot 8 \mathrm{H}_{2} \mathrm{O}$, to 18 in order to study the influence of a quinone function on the thermal isomerization. Starting from a single isomer of dipyrrolidinyl quinone 15

(18) Under hydrolytic conditions (4 $\mathrm{M} \mathrm{HCl} / 1,4$-diozane $\left./ 40^{\circ} \mathrm{C}\right) 12$ decomposed and since the corresponding $o$-quinone might be a suitable precursor for the desired $p$-quinone $13,19,20$ we prepared this o-quinone by reacting the bis(cyclohexylidene) ketal 12 with ceric ammonium nitrate (CAN) ${ }^{19}$ Unfortunately, we were not able to convert this o-quinone into the corresponding $p$-quinone 13.

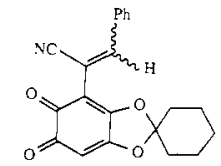

(19) Dallacker, F.; Loehnert, G. Chem. Ber. 1972, 105, 614.

(20) Wanzlick, H.-W.; Jahnke, U. Chem. Ber. 1968, 101, 3744.

(21) Other methods to methylate 13 by using $\mathrm{Me}_{2} \mathrm{SO}_{4}$ or $\mathrm{MeI}$ failed. On a larger scale the methylation gave yields ranging from $30 \%$ to $37 \%$. 
the corresponding dimethyl hydroquinone 18 was obtained as a mixture of $E / Z$ isomers in a yield of $50 \%$. The ${ }^{1} \mathrm{H}$ NMR spectrum of 18 revealed among other signals at $\delta$ 6.39 and 6.34 (s, $\mathrm{Ar} \mathrm{H}), 3.80,3.56$, and $3.51(\mathrm{~s}, 3 \mathrm{H}, 6 \mathrm{H}$, and $3 \mathrm{H}$, respectively, $\left.\mathrm{OCH}_{3}\right)$, and $3.5-3.0\left(\mathrm{~m}, \mathrm{NCH}_{2}\right)$. The dimethyl dipiperidinyl hydroquinone 19 was prepared analogously as a single isomer in a yield of $49 \%$.

The starting amino quinones 32-37 in the naphthoquinone series were prepared in several steps from the known dibromide $20.22,23$ Treatment of 20 with $\mathrm{KCN}$ and 18-crown- 6 in refluxing acetonitrile gave the benzyl cyanide 21, which was used as a starting material in all condensation reactions (Chart III). The $\alpha$-phenylmethylene group was subsequently introduced by a reaction with benzaldehyde in methanol using sodium methoxide as a base; the overall yield of both reactions was $70 \%$. Compound 22 was obtained as a mixture of $E / Z$ isomers, which could be separated by chromatography to afford one isomer as a solid, while the other was isolated as an oil. Both isomers of $\mathbf{2 2}$ underwent oxidative demethylation upon treatment with ceric ammonium nitrate (CAN) in acetonitrile-water to afford the corresponding isomer of quinone 28 in a yield of $65 \%$. In the case of the solid isomer of 28 the presence of a $\mathrm{C}=\mathrm{O}$ function was clearly demonstrated by an absorption at $1680 \mathrm{~cm}^{-1}$ in the IR spectrum and by signals at $\delta 182.8$ (s) and 178.9 (s) in the ${ }^{13} \mathrm{C}$ NMR spectrum. The bromine atom in quinone 28 was easily substituted by pyrrolidine, giving a mixture of $E / Z$ isomers ${ }^{24}$ of the pyrrolidinyl quinone 32 in a yield of $80 \%$. The ${ }^{1} \mathrm{H}$ NMR spectrum of 32 revealed signals at $\delta 8.15-7.25[\mathrm{~m}$, $10 \mathrm{H}, \mathrm{Ar} \mathrm{H}, \mathrm{Ph} \mathrm{H}$, and $=\mathrm{CHPh}$ (major isomer)], 6.99 [s, $=\mathrm{CHPh}$ (minor isomer)], 3.9-3.6 [m, $\mathrm{NCH}_{2}$ (major isomer)], 3.55-3.25 [m, $\mathrm{NCH}_{2}$ (minor isomer)]. The piperidinyl quinone 37 was prepared in an analogous way to afford a mixture of $E / Z$ isomers ${ }^{24}$ in a yield of $80 \%$.

The amino naphthoquinone 32 was converted into the corresponding dimethyl hydroquinone 38 (Chart IV) by reductive methylation in the same way as dipyrrolidinyl quinone 15 (vide supra). The $E$ and $Z$ isomers of 38 could be separated by chromatography, but the individual structures of the isomers have not been determined.

In order to study the influence of electron-donating substituents at the $\beta$-carbon atom of the vinyl moiety, we have prepared several substituted naphthohydroquinones (23, 25-27). The sodium salt of $\alpha$-(hydroxymethylene)benzeneacetonitrile 23 was synthesized by condensation of benzeneacetonitrile 21 with ethyl formate and sodium hydride as a base in toluene $e^{25}$ in a yield of $84 \%$. Since neither $\alpha$-(hydroxymethylene) benzeneacetonitrile 23 nor the corresponding methyl enol ether ${ }^{26,27}$ could be transformed into the corresponding $p$-quinone, we decided to

(22) Syper, L.; Mlochowski, J.; Kloc, K. Tetrahedron 1983, 39, 781 (23) Adams, R.; Geissman, T. A.; Baker, B. R.; Teeter, H. M. J. Am. Chem. Soc. 1941, 63, 533 .

(24) In the case of 32 and 37 the isomers can be observed as separate spots on TLC $\left(\mathrm{CH}_{2} \mathrm{Cl}_{2} /\right.$ ethyl acetate, $\left.97: 3\right)$. They cannot be separated because they isomerize at room temperature in solution.

(25) Cariou, M. Bull. Soc. Chim. Fr. 1969, 198.

(26) A reaction of the sodium salt of 23 with dimethyl sulfate in acetonitrile gave the corresponding $\alpha$-(methoxymethylene) benzeneacetonitrile. However, this methylated hydroquinone could not be converted into the corresponding $p$-quinone. Oxidative demethylation using CAN, Fremy's salt, argentic oxide, ${ }^{27}$ or silver(II) dipicolinate ${ }^{22}$ only gave decomposition.

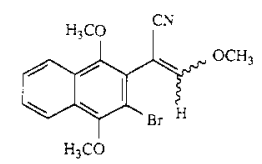

(27) Snyder, C. D.; Rapoport, H. J. Am. Chem. Soc. 1972, 94, 227.

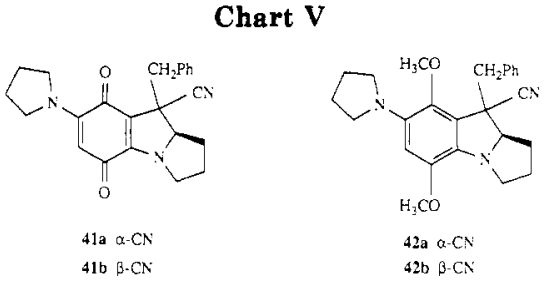

prepare the thio enol ether 25. Starting from $\alpha$-(hydroxymethylene) benzeneacetonitrile 23, obtained after acidification of its sodium salt, the phenylthio enol ether $\mathbf{2 5}$ could be synthesized in pyridine using tosyl chloride and thiophenol. ${ }^{28}$ After workup, in addition to the desired thio enol ether 25 , which was obtained in $70 \%$ yield, $5 \%$ of the tosylate intermediate 24 was also isolated. Proof for the structure of 24 was obtained from the spectroscopic data. The IR spectrum showed absorptions at $2210 \mathrm{~cm}^{-1}(\mathrm{CN})$ and at 1350 and $1180 \mathrm{~cm}^{-1}\left(\mathrm{OSO}_{2}\right)$. In addition, the ${ }^{1} \mathrm{H}$ NMR spectrum exhibited signals at $\delta 8.2-7.9$ and $7.8-7.25$ $(\mathrm{m}, \mathrm{Ar} \mathrm{H}, \mathrm{Ph} \mathrm{H}$ and $=\mathrm{CHPh}), 3.93$ and $3.78\left(\mathrm{~s}, \mathrm{OCH}_{3}\right)$, and $2.47\left(\mathrm{~s}, \mathrm{CH}_{3}\right)$. Phenylthio enol ether 25 was isolated as a mixture of $E / Z$ isomers, as shown by absorptions in the ${ }^{1} \mathrm{H}$ NMR spectrum at $\delta 4.03,3.98$, and $3.95(\mathrm{~s}, 3 \mathrm{H}, 6$ $\mathrm{H}$, and $3 \mathrm{H}$, respectively, $\mathrm{OCH}_{3}$ ) and by two signals of the $\mathrm{CN}$ group at 2250 and $2210 \mathrm{~cm}^{-1}$ in the IR spectrum. The hydroquinone 25, containing a phenylthio enol ether moiety, was converted into the corresponding $p$-quinone 29 by using CAN. Subsequent treatment of this unstable bromo quinone 29 with pyrrolidine in benzene-ethanol, in the same way as described for the synthesis of 32 (vide supra), gave the pyrrolidinyl quinone $\mathbf{3 3}$ as one isomer in an overall yield of $34 \%$. The synthesis of the protected hydroquinone derivative 39 was accomplished by reductive acylation using zinc dust in acetic anhydride in the presence of triethylamine as a base ${ }^{29}$ to give a mixture of $E$ and $Z$ isomers of 1,4-bis(acetyloxy)naphthaleneacetonitrile 39 in $41 \%$ yield. Condensation of benzyl cyanide 21 with carbon disulfide in the presence of potassium tert-butoxide $^{30}$ in THF, followed by dialkylation with 1,3-dibromopropane or 1,2-dibromoethane, gave the ketene dithioacetals 26 and 27 , respectively. Oxidative demethylation of these dimethyl hydroquinones 26 and 27 using CAN gave the corresponding quinones 30 and 31 , respectively. Substitution of the bromine atom in 30 by pyrrolidine afforded 34 . In the same way, we prepared 35 from 31. Since electron-donating substituents at the $\beta$-carbon atom of the vinyl moiety lower the rate of the thermal isomerization, ${ }^{5}$ we also converted 35 into the ketene dithioacetal $S$-monooxide 36 by careful oxidation with $m$ chloroperbenzoic acid. ${ }^{31}$ The presence of the electronwithdrawing sulfoxide in $\mathbf{3 6}$ should enable a faster 1,5electrocyclization. In analogy with the reductive acylation of the phenylthio enol ether 33, we converted ketene dithioacetal 34 into the corresponding diacetate $\mathbf{4 0}$.

Thermal Cyclization. Heating of the dipyrrolidinyl quinone 15 in toluene or in 1-butanol gave a mixture of cis- and trans-2,3,5,8,9,9a-hexahydro-5,8-dioxo-9-(phenylmethyl)-7-(1-pyrrolidinyl)-1H-pyrrolo[1,2-a] indole-9carbonitrile (41a and $41 \mathrm{~b}$ ), respectively (Chart V). The ratio of cis and trans isomers $41 \mathrm{a}$ and $41 \mathrm{~b}$ depends on the solvent. In 1-butanol the reaction proceeded at $100^{\circ} \mathrm{C}$ in $3 \mathrm{~h}$ to give a mixture of $41 \mathrm{a}$ and $41 \mathrm{~b}$ in a ratio of about

(28) Ireland, R. E.; Marshall, J. A. J. Org. Chem. 1962, 27, 1615.

(29) Baker, B. R.; Davis, T. H.; McElroy, L.; Carlson, G. H. J. Am. Chem. Soc. 1942, 64, 1096

(30) Corey, E. J.; Chen, R. H. K. Tetrahedron Lett. 1973, 3817.

(31) The unstable ketene dithioacetal $S$-monoxide 36 was not purified but immediately used in the thermal isomerization experiment. 


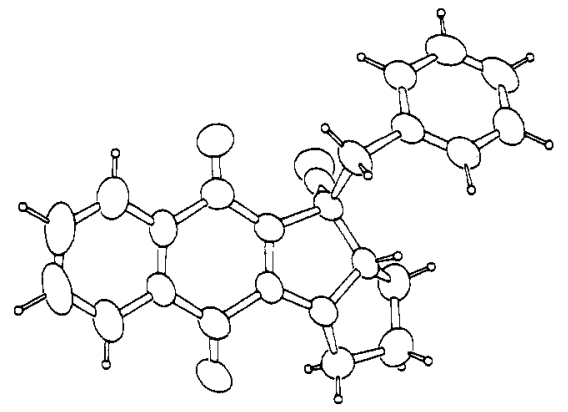

Figure 1. X-ray crystal structure of 43.

$2: 1$. In toluene a complete conversion of starting material 15 was accomplished at $100^{\circ} \mathrm{C}$ in $8 \mathrm{~h}$, giving $41 \mathrm{a}$ and $41 \mathrm{~b}$ in a ratio of about 1:2. The assignment of the stereochemistry of the isomers is based upon comparison of the characteristic $\mathrm{NMR}$ data, i.e. the $\mathrm{CH}_{2} \mathrm{Ph}$ hydrogen atoms and $\mathrm{NCH}$ and the $\mathrm{CH}_{2} \mathrm{Ph}$ carbon atoms, with those of the trans-naphthoquinone 43 (vide infra), the structure of which has been unequivocally determined by X-ray analysis. In the ${ }^{1} \mathrm{H} \mathrm{NMR}$ spectrum the $\mathrm{CH}_{2} \mathrm{Ph}$ absorptions of $41 \mathrm{a}$ (cis) are present at $\delta 4.02$ and 2.95 (AB q, $J=15.0$ $\mathrm{Hz}$ ), while those of $41 \mathrm{~b}$ are situated at approximately $\delta$ $3.9^{32}$ and $3.00\left(\mathrm{AB} \mathrm{q}, J=13.7 \mathrm{~Hz}\right.$ ). In addition, the ${ }^{13} \mathrm{C}$ NMR spectra of 41 exhibited $\mathrm{CH}_{2} \mathrm{Ph}$ and $\mathrm{NCH}$ signals of $41 \mathrm{a}$ at $\delta 37.8$ and 75.0 , respectively, and $\mathrm{CH}_{2} \mathrm{Ph}$ and $\mathrm{NCH}$ signals of $41 \mathrm{~b}$ at $\delta 42.1$ and 72.5 , respectively.

Conversion of the $E / Z$ mixture of the corresponding dipyrrolidinyl hydroquinone $18^{33}$ required refluxing in 1-butanol for $116 \mathrm{~h} .{ }^{34}$ After chromatography the cis-and trans-tetrahydro- $1 H$-pyrrolo[1,2-a]indoles (42a and 42b) were isolated in yields of $85 \%$ and $5 \%$, respectively. The structural assignment of these isomers is based upon comparison of the characteristic NMR data, i.e. the $\mathrm{CH}_{2} \mathrm{Ph}$ hydrogen atoms and the $\mathrm{NCH}$ and $\mathrm{CH}_{2} \mathrm{Ph}$ carbon atoms, with those of similar tetrahydro-1H-pyrrolo[1,2-a]indoles. ${ }^{3,10 \mathrm{~b}}$ In the ${ }^{1} \mathrm{H}$ NMR spectrum of $42 \mathrm{a}$ the $\mathrm{CH}_{2} \mathrm{Ph}$ absorptions are present at $\delta 4.10$ and $3.13(\mathrm{AB} \mathrm{q}, J=15.2$ $\mathrm{Hz}$ ), while those of $\mathbf{4 2 b}$ are situated at approximately $\delta$ $4.2^{32}$ and $2.78(\mathrm{AB} \mathrm{q}, J=13.4 \mathrm{~Hz})$. In addition, the ${ }^{13} \mathrm{C}$ NMR spectrum of cis isomer 42a exhibited $\mathrm{CH}_{2} \mathrm{Ph}$ and $\mathrm{NCH}$ signals at $\delta 39.3$ and 74.4 , respectively, while the corresponding absorptions of $42 \mathrm{~b}$ are situated at $\delta 45.2$ and 73.0 , respectively. ${ }^{35}$ The dipiperidinyl and dimorpholinyl quinones 16 and 17 , respectively, could not be thermally isomerized due to decomposition when heated.

Refluxing naphthoquinone 32 in 1-butanol for $3 \mathrm{~h}$ gave only one isomer of $1 H$-benzo[f]pyrrolo[1,2-a]indole 43 in a yield of $70 \%$. From the characteristic absorptions at $\delta$ 3.86 and $3.10\left(\mathrm{AB} \mathrm{q}, J=13.9 \mathrm{~Hz}, \mathrm{CH}_{2} \mathrm{Ph}\right)$ in the ${ }^{1} \mathrm{H}$ NMR

(32) This part of the $A B$ system overlapped with the signals of the $\mathrm{NCH}_{2}$ moiety.

(33) When a mixture of $E / Z$ isomers of the dipiperidinyl hydroquinone 19 was heated in 1-butanol or toluene decomposition occurred.

(34) In refluxing toluene or mesitylene no cyclization took place.

(35) Oxidative demethylation of the hydroquinone 42 with CAN gave a red compound in low yield (18\%). The $\mathrm{M}^{+}$value $399.192\left(\mathrm{M}^{+}\right.$, calcd for $\mathrm{C}_{25} \mathrm{H}_{25} \mathrm{~N}_{3} \mathrm{O}_{2} 399.195$ ) is in agreement with 5,8-dimethoxy-9-(phenylmethyl)-7-(1-pyrrolidinyl)-9H-pyrrolo[1,2-a]indole-9-carbonitrile (vide infra) and in the ${ }^{1} \mathrm{H}$ N.MR spectrum typical absorptions, which correspond with those of the previously described 5-amino-7-methoxy-6methyl-9-(phenylmethyl)-9H-pyrrolo[1,2-a] indole-9-carbonitrile, ${ }^{10 b}$ are located at $\delta 6.25-6.15$ (m, H-2) and at $\delta 5.88$ (dd, $J=3.7$ and $1.0 \mathrm{~Hz}, \mathrm{H}-1$ ) Previously, we have reported ${ }^{10 \mathrm{~b}}$ that a similar pyrrolo[1,2-a]indole un derwent aromatization under oxidative conditions, i.e. using Fremy's salt.

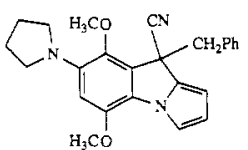

Chart VI
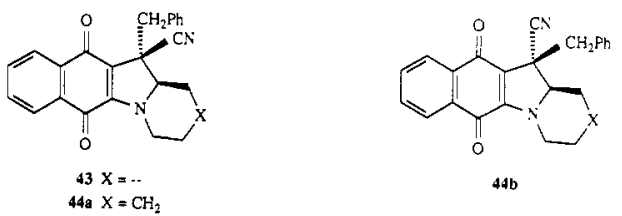

$44 b$
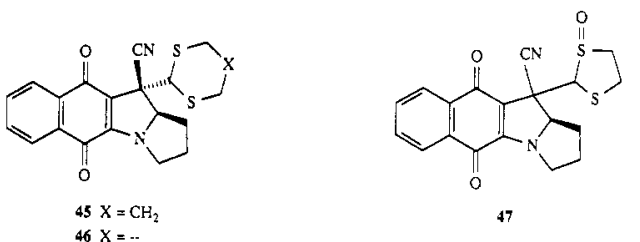

spectrum and at $\delta 71.5(\mathrm{NCH})$ and $42.2\left(\mathrm{CH}_{2} \mathrm{Ph}\right)$ in the ${ }^{13} \mathrm{C}$ NMR spectrum a definite assignment of the stereochemistry was not possible. However, the definite structure proof was given by X-ray analysis (Figure 1), which revealed that $\mathbf{4 3}$ has the trans configuration. When the amino quinone 32 was refluxed in toluene for $8 \mathrm{~h}$, again the trans isomer was obtained as the single cyclization product but only in a yield of $33 \%$. Thermal cyclization of piperidinyl quinone 37 in refluxing 1-butanol gave after $3 \mathrm{~h}$ in $25 \%$ overall yield a mixture of the trans- and cis$1 H$-benzo[f]pyrido[1,2-a]indoles $44 \mathrm{a}$ and $44 \mathrm{~b}$, respectively, in a ratio of 20:1 (Chart VI). Since a considerable amount of decomposition was observed in this reaction, we decided to investigate the stability of the products formed by refluxing for an additional $3 \mathrm{~h}$ in 1-butanol. Both products remained stable and therefore we concluded that only the starting amino quinone 37 decomposes under the conditions used in the cyclization. The structural assignment of the trans- and cis-1H-benzo[f]pyrido[1,2-a]indoles 44a and 44b is based upon comparison of the characteristic NMR data with those of trans- $1 H$-benzo[f]pyrrolo[1,2a]indole 43. In the ${ }^{1} \mathrm{H}$ NMR spectrum of the trans isomer 44a, the NCH signals are present at $\delta .8-4.55(\mathrm{~m})$ and the $\mathrm{CH}_{2} \mathrm{Ph}$ absorptions at $\delta 3.53$ and 3.11 ( $\mathrm{AB} \mathrm{q}, J=13.9 \mathrm{~Hz}$ ), while for the cis isomer $44 \mathrm{~b}$ these absorptions are situated at $\delta 5.1-4.8(\mathrm{~m})$ and $3.35-3.0(\mathrm{~m})$, respectively. The trans isomer 44a exhibited absorptions at $\delta 67.9(\mathrm{NCH})$ and 41.7 $\left(\mathrm{CH}_{2} \mathrm{Ph}\right)$ in the ${ }^{13} \mathrm{C}$ NMR spectrum, while the corresponding signals of the cis isomer $44 \mathrm{~b}$ are found at $\delta 72.0$ and 36.7 .

The corresponding dimethoxynaphthalene 38 did not cyclize in 1-butanol or mesitylene upon refluxing for 14 days; only decomposition of 38 was observed.

Heating of quinone 33 in 1-butanol ${ }^{36}$ for $8 \mathrm{~h}$ at $90^{\circ} \mathrm{C}$ gave in addition to starting material $(10 \%)$ the indoline 50 in a yield of $20 \%$. The mass spectrum of 50 revealed a $\left(\mathrm{M}^{+}-2\right)$ peak for $\mathrm{C}_{27} \mathrm{H}_{26} \mathrm{~N}_{2} \mathrm{O}_{3} \mathrm{~S}$, i.e. the sum of the molecular formula of starting compound $33\left(\mathrm{C}_{23} \mathrm{H}_{18} \mathrm{~N}_{2} \mathrm{O}_{2} \mathrm{~S}\right)$ and 1-butanol minus $2 \mathrm{H}$. The ${ }^{1} \mathrm{H}$ NMR spectrum exhibited among others multiplets at $\delta 4.8-4.7(1 \mathrm{H}, \mathrm{CHCN})$, 3.9-3.75 (1 H, NCHS), 3.7-3.2 (6 H, $2 \times \mathrm{OCH}_{2}$ and $\left.\mathrm{NCH}_{2}\right)$ and 2.25-1.15 $\left(8 \mathrm{H}, \mathrm{CH}_{2}\right)$. The corresponding diacetate 39 , in which the quinone function is absent, failed to undergo thermal isomerization.

Refluxing the ketene dithioacetal 34 for 10 days in 1butanol gave the cis isomer $\mathbf{4 5}^{37}$ in $80 \%$ yield. The

(36) In DMSO or toluene at $90^{\circ} \mathrm{C}$ only decomposition of starting material took place.

(37) It should be noticed that the nomenclature of the stereochemistry of compound 45 is just opposite that of the other pyrrolo[1,2-a]indoles, e.g. 43 (compare Section 203 of Appendix IV to the 1984 Chemical Abstracts Index Guide); the relative stereochemistry of $\mathrm{C}-1$ and $\mathrm{CN}$ is the same. 


\section{Scheme I}

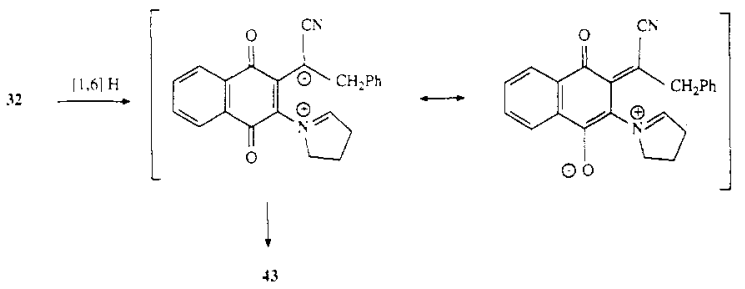

structural assignment of $\mathbf{4 5}$ is based on comparison of the characteristic ${ }^{13} \mathrm{C}$ NMR data with those of trans $-1 H$ benzo[f]pyrrolo[1,2-a]indole 43 , more specifically the C-11 and $\mathrm{NCH}$ absorptions of $\mathbf{4 5}$ which are situated at $\delta 52.3$ and 70.1 , respectively. In toluene the cyclization took place in low yield (10\%) to the cis isomer. The ketene dithioacetal $\mathbf{3 5}$ was converted very slowly into $c i s-1 H$-benzo[f]pyrrolo[1,2-a]indole 46, after 30 days of refluxing in 1butanol only $40 \%$ had reacted. The assignment of the stereochemistry of $\mathbf{4 6}$ is based on comparison of the characteristic NMR data with those of 45 and 43 . In case of the ketene dithioacetal $S$-monooxide 36 , in which one of the sulfur atoms is oxidized, the thermal rearrangement to 47 in refluxing 1-butanol was very fast $(1.5 \mathrm{~h})$. The resulting reaction mixture contained several isomers of 47 , which were not separated. ${ }^{38}$ The corresponding ketene dithioacetal diacetate $\mathbf{4 0}$ did not undergo cyclization either in mesitylene or in DMSO.

\section{Discussion}

Despite the fact that in the (dialkylamino) quinones, e.g. 15 and 32, the nitrogen lone pair constitutes part of a vinylogous amide system, which might render $[1,6]$ hydrogen transfer unfavorable due to a lower electron density at the nitrogen atom, experimentally a very fast cyclization is observed. Therefore we conclude that the predominant effect of a quinone function is the stabilization of the negative end of the 1,5-dipole that is formed upon a thermal antarafacial ${ }^{39}[1,6]$ hydrogen transfer (Scheme I).

This is clearly demonstrated when we compare the rates of the thermal isomerization of the dipyrrolidinyl hydroquinone 18 and the corresponding dipyrrolidinyl quinone 15 , which cyclizes with a rate that is about 42 times faster. ${ }^{40}$ Of the examples described in the present study dipyrrolidinyl hydroquinone 18 is the only hydroquinone which undergoes a thermal rearrangement, in contrast to the cyclization of most of the quinones. Since we have proven that the $[1,6]$ hydrogen transfer comprises the rate-determining step in the thermal isomerization, ${ }^{4}$ groups stabilizing the 1,5-dipole will lower the activation energy. In the case of 18, which lacks the stabilizing effect of a quinone function, additional stabilization of the positive end of the 1,5-dipole is provided by the field and inductive

(38) The isomers could be partly separated by chromatography (Et$O A c)$. The overall yield of the oxidation reaction of 35 and the thermal isomerization of 36 was $50 \%$. Mass spectrum of $47, \mathrm{~m} / \mathrm{e} 484.058\left(\mathrm{M}^{+}\right.$ calc for $\mathrm{C}_{19} \mathrm{H}_{16} \mathrm{~N}_{2} \mathrm{O}_{3} \mathrm{~S}_{2}$ 484.060). Characteristic ${ }^{1} \mathrm{H}$ NMR data of three isomers $\left(\mathrm{CDCl}_{3}, \delta\right)$ :

$\begin{array}{lccc} & \text { CHSO (s) } & \text { NCH }[\mathrm{AB} \mathrm{q}, J(\mathrm{~Hz})] & \mathrm{CH}_{2} \mathrm{SO}(\mathrm{m}) \\ \mathrm{A} & 6.00 & 4.674 .62(5.8) & 3.75-3.62 .8-2.6 \\ \mathrm{~B} & 5.59 & 4.874 .82(6.0) & 3.7-3.553 .0-2.75 \\ \mathrm{C} & 4.19 & 4.844 .79(5.8) & 3.7-3.553 .0-2.8\end{array}$

(39) (a) This shift is electronically equivalent with a $[1,7]$ hydrogen shift in an all carbon system ${ }^{39 b}$ since the lone pair of the nitrogen atom contributes two $\pi$-electrons. (b) Woodward, R. B.; Hoffmann, R. J. Am. Chem. Soc. 1965, 87, 2511.

(40) In refluxing 1-butanol dipyrrolidinyl quinone 15 cyclizes in about $2 \mathrm{~h}$ and $45 \mathrm{~min}$.
(-I) effects of the pyrrolidinyl group in the para position.

Stabilization of the intermediate iminium ion in the 1,5-dipole is mainly dependent on the efficiency of the overlap between the lone pair of the nitrogen atom and the $\pi$-system of the aromatic ring. ${ }^{3,41}$ This effect may be the reason why dipiperidinyl hydroquinone 19 and both the quinones 16 and 17 do not undergo a thermal rearrangement. On the other hand, piperidinyl naphthoquinone 37 isomerizes thermally to the $1 H$-benzo[f]pyrido[1,2-a]indole 44. A comparison of the cyclization rates of pyrrolidinyl naphthoquinones 32 to 43 and piperidinyl naphthoquinone 37 to 44 , however, is complicated by the fact that extensive decomposition of 37 occurs on heating. The reason why piperidinylnaphthoquinone $\mathbf{3 7}$ cyclizes to 44 while both dipiperidinyl- and dimorpholinylbenzoquinone (16 and 17) do not rearrange thermally may be that $\mathbf{3 7}$ possesses more "enamine character" which renders a $[1,6]$ hydrogen transfer more facile. ${ }^{42,43}$ In agreement with earlier studies ${ }^{5}$ the presence of an electron-donating group at the $\beta$-carbon atom of the vinyl moiety lowers the rate of cyclization, because a decrease of the electron density at the adjacent carbon atom will make the $[1,6]$ hydrogen shift less favorable. Due to the quinone moiety in $\mathbf{3 4}$ this compound undergoes a thermal rearrangement to the $1 H$-benzo[f]pyrrolo[1,2-a]indole 45, despite of the fact that two "destabilizing substituents" of a ketene dithioacetal moiety are present at the $\beta$-carbon atom of the vinyl group. In analogy with the thermal isomerization of 34 to 45 , the ketene dithioacetal derivative 35 , containing a five-membered ring, also cyclizes to the $1 H$-benzo[f]pyrrolo[1,2-a]indole 46 , although much slower than the ketene dithioacetal 34. The explanation for this difference may be found in the relative torsional strain in the two systems, according to the concept of I strain. ${ }^{44-47}$ A conversion of the $\mathrm{sp}^{2}$-hybridized carbon atom in the five-membered ketene dithioacetal to $\mathrm{sp}^{3}$ increases the number of eclipsing interactions. A similar process in the six-membered ketene dithioacetal leads to a completely staggered arrangement of bonds. In addition, the effect of an electron-donating group at the $\beta$-carbon atom of the vinyl moiety is clearly demonstrated by comparing the rates of cyclization of 32 with 34 and 35 , i.e. $3 \mathrm{~h}$ for 32,10 days for 34 , and about 75 days for 35 . Moreover, this influence is shown by oxidation of one of the sulfur atoms in $\mathbf{3 5}$ to the ketene dithioacetal $S$ monooxide 36. As a result 36 cyclizes in $1.5 \mathrm{~h}$ to 47 .

Our work on the thermal rearrangement of 1-(1pyrrolidinyl)-2-vinylbenzene derivatives 1 has revealed the crucial role of the solvent both on the rate of the cyclization and on the stereochemistry of the products $2 .^{3,5,10 \mathrm{~b}}$ In apolar solvents the 1,5-dipolar intermediate, e.g. 3 , is not stabilized and stereomutation does not occur, resulting in the formation of the trans isomer. In polar solvents stereomutation of the 1,5-dipolar intermediates generally occurs, ${ }^{4}$ as a result of a better solvation of the intermediate, to give the cis isomer. However, it appears that in the pyrrolidinyl naphthoquinones 32,34 , and 35 the solvent has no influence on the stereochemistry of the product.

(41) Effenberger, F.; Fischer, P.; Schoeller, W. V.; Stohrer, W.-D. Tetrahedron $1978,34,2409$.

(42) E.g. 2-(1-pyrrolidinyl)-1,4-naphthoguinone reacts with DMAD in 1-butanol at $70^{\circ} \mathrm{C},{ }^{9}$ while 2-(1-pyrrolidinyl)-1,4-benzoquinone derivatives do not react with DMAD at all. ${ }^{3}$

(43) Verboom, W.; Reinhoudt, D. N. Recl. Trav. Chim. Pays-Bas 1986, $105,199$.

(44) Pasto, D. J.; Gontarz, J. A. J. Am. Chem. Soc. 1971, 93, 6909.

(45) Brown, H. C. J. Org. Chem. 1957, 22, 439.

(46) Brown, H. C.; Brewster, J. H; Shechter, H. J. Am. Chem. Soc $1954,76,467$.

(47) Brown, H. C. Tetrahedron 1957, 1, 221. 
Scheme II

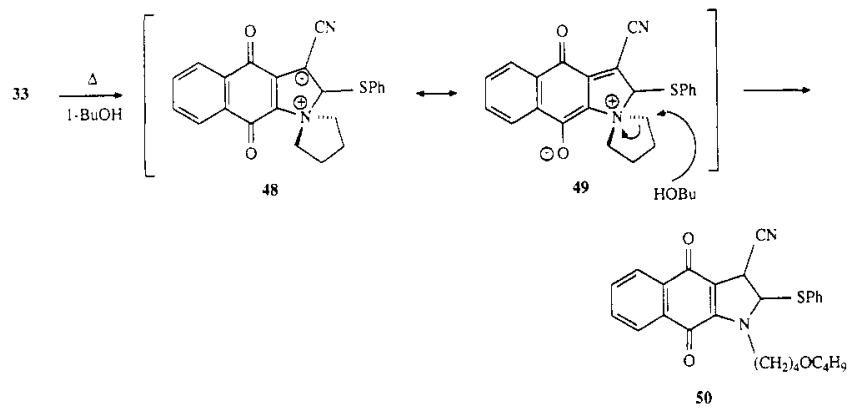

In a polar solvent like 1-butanol or in apolar solvents like toluene or mesitylene, the relative stereochemistry of $\mathrm{H}$-11a and $\mathrm{CN}$ in the $1 H$-benzo[f]pyrrolo[1,2-a]indoles 43, 45, and 46 is the same, i.e. trans. Most likely, the quinone function fixes the intermediate formed by the concerted $[1,6]$ hydrogen shift (Scheme I). The results of the thermal isomerization of 15 show that the trans isomer is the major isomer when toluene is used as a solvent, while in 1-butanol the cis isomer is the major product. ${ }^{48}$ When dipyrrolidinyl hydroquinone 18 is refluxed in 1 -butanol the cis isomer 42a is formed predominantly, in agreement with the mechanism of the concerted disrotatory 1,5-electrocyclization, which we have discussed previously.,4

Finally, the formation of indoline 50 represents another variation of the "tert-amino effect". 5 We assume that a spiro intermediate such as 48 is formed, which is stabilized by resonance (49); subsequently, a nucleophilic attack by a solvent molecule yields indoline 50 (Scheme II).

We are aware that the formation of $\mathbf{5 0}$ is not in agreement with Baldwin's rules, i.e. the conversion of 33 into 50 is an example of a 5-Endo-Trig ring closure. ${ }^{49-51}$ However, the formation of $\mathbf{5 0}$ is not the only example of a 5-Endo-Trig reaction pathway we have found, because previously we reported ${ }^{5}$ the synthesis of 1 -alkylindoles, that represents a similar variation of the "tert-amino effect".

\section{Conclusion}

We can conclude that a quinone function has an accelerating effect on the 1,5-electrocyclization and it appears that the rate of $[1,6]$ hydrogen transfer is most influenced by the stabilization of the negative end of the intermediate 1,5-dipole. The use of this principle constitutes a simple method for the synthesis of pyrrolo[1,2-a]indoles containing a $p$-quinone function. Further work on the synthesis of isomitosanes using this methodology is in progress.

\section{Experimental Section}

Melting points were determined with a Reichert melting point apparatus and are uncorrected. ${ }^{1} \mathrm{H}$ NMR spectra $\left(\mathrm{CDCl}_{3}\right)$ were recorded with a Bruker WP- 80 spectrometer and ${ }^{13} \mathrm{C}$ NMR spectra $\left(\mathrm{CDCl}_{3}\right)$ were recorded with a Nicolet MT 200 spectrometer $\left(\mathrm{Me}_{4} \mathrm{Si}\right.$ as an internal standard). Mass spectra were recorded with a Varian MAT 311A spectrometer and IR spectra with a PerkinElmer 257 spectrophotometer. Elemental analyses were carried out by E. Hoogendam and A. Christenhusz of the Laboratory of Chemical Analysis of the University of Twente.

$\mathrm{CH}_{2} \mathrm{Cl}_{2}$ was distilled from $\mathrm{P}_{2} \mathrm{O}_{5}$; THF from sodium/benzophenone ketyl. Petroleum ether refers to the fraction with bp $60-80^{\circ} \mathrm{C}$.

(48) The reason why stereomutation occurs during the thermal isomerization of 15 may be attributed to the presence of the $p$-amino group, which may compensate for the effect of fixation of the quinone function.

(49) Baldwin, J. E. J. Chem. Soc., Chem. Commun. 1976, 734.

(50) Baldwin, J. E.; Cutting, J.; Dupont, W.; Kruse, L.; Silberman, L.; Thomas, R. C. J. Chem. Soc., Chem. Commun. 1976, 736.

(51) Baldwin, J. E. J. Chem. Soc., Chem. Commun. 1976, 738.
Column chromatography was performed with silica gel. All reactions were carried out under a nitrogen atmosphere.

Dispiro[cyclohexane-1,2'-benzo[1,2-d:4,5-d] $]$ bis [1,3]dioxole- $6^{\prime}, 1^{\prime \prime}$-cyclohexane]- $4^{\prime}$-carboxaldehyde (8). To a solution of $7^{13,14}(6.04 \mathrm{~g}, 20.0 \mathrm{mmol})$ in THF $(85 \mathrm{~mL})$ was added $n$-BuLi $\left(16.3 \mathrm{~mL}, 22.0 \mathrm{mmol}, 1.35 \mathrm{M}\right.$ solution in hexane) at $0^{\circ} \mathrm{C}$, while the temperature was kept below $5^{\circ} \mathrm{C}$. Subsequently, the mixture was stirred for $30 \mathrm{~min}$ at $0^{\circ} \mathrm{C}, 2 \mathrm{~h}$ at room temperature, and 10 $\min$ at $35^{\circ} \mathrm{C}$. The solution was cooled to $0^{\circ} \mathrm{C}$ followed by the addition of DMF $(3.04 \mathrm{~g}, 40.0 \mathrm{mmol})$ at such a rate that the temperature did not rise above $10^{\circ} \mathrm{C}$. Subsequently, the reaction mixture was allowed to warm to room temperature. After being stirred for $17 \mathrm{~h}$, the resulting solution was concentrated to $30 \mathrm{~mL}$, water $(50 \mathrm{~mL})$ was added, and the mixture was extracted with $\mathrm{CHCl}_{3}(3 \times 100 \mathrm{~mL})$. The combined organic layers were washed with a saturated $\mathrm{NH}_{4} \mathrm{Cl}$ solution $(100 \mathrm{~mL})$ and water $(100 \mathrm{~mL})$, dried with $\mathrm{MgSO}_{4}$, and evaporated. The crude residue was triturated with $\mathrm{MeOH}$ to give pure 8: yield 83\%; mp 154-156 ${ }^{\circ} \mathrm{C}(\mathrm{MeOH}) ;{ }^{1} \mathrm{H}$ NMR $\delta 10.11(\mathrm{~s}, 1 \mathrm{H}, \mathrm{CHO}), 6.53(\mathrm{~s}, 1 \mathrm{H}, \mathrm{Ar} \mathrm{H})$, 2.1-1.3 (m, $\left.20 \mathrm{H}, \mathrm{CH}_{2}\right) ;{ }^{13} \mathrm{C} \mathrm{NMR}^{52} \delta 185.4$ (d, CHO), 140.8 (s, C-3'a), 120.9 (s, C-4'), 106.5 (s, C-1), $98.3\left(\mathrm{~d}, \mathrm{C}-8^{\prime}\right), 43.9$ (t, C-2), $24.5(\mathrm{t}, \mathrm{C}-4), 23.2(\mathrm{t}, \mathrm{C}-3)$; IR $(\mathrm{KBr}) 1695(\mathrm{C}=\mathrm{O}) \mathrm{cm}^{-1}$; mass spectrum, $m / e 330.145\left(\mathrm{M}^{+}\right.$, calcd 330.147$)$.

Anal. Calcd for $\mathrm{C}_{19} \mathrm{H}_{22} \mathrm{O}_{5}\left(M_{\mathrm{r}} 330.382\right)$ : C, 69.07; H, 6.71. Found: C, 68.81; H, 6.66.

Dispiro[cyclohexane-1,2'-ben zo[1,2-d:4,5-d'] bis [1,3]dioxole- $6^{\prime}, 1^{\prime \prime}$-cyclohexane]-4'-methanol (9). To a solution of 8 $(5.51 \mathrm{~g}, 17.0 \mathrm{mmol})$ in a mixture of THF, $\mathrm{MeOH}$, and water (6:1:1, total volume $640 \mathrm{~mL}$ ) was added a portion of $\mathrm{NaBH}_{4}(1.30 \mathrm{~g}, 34.2$ mmol). After stirring for $1.5 \mathrm{~h}$, another portion of $\mathrm{NaBH}_{4}(0.50$ $\mathrm{g}, 13.2 \mathrm{mmol}$ ) was added and stirring was continued for $1.5 \mathrm{~h}$. Subsequently, the reaction mixture was concentrated to $150 \mathrm{~mL}$ and the resulting solution was extracted with EtOAc $(3 \times 150 \mathrm{~mL})$. The combined organic layers were washed with a saturated $\mathrm{NH}_{4} \mathrm{Cl}$ solution $(2 \times 150 \mathrm{~mL})$ and water $(100 \mathrm{~mL})$, dried with $\mathrm{MgSO}_{4}$, and evaporated. The crude compound was purified by chromatography $\left(\mathrm{CHCl}_{3}\right)$ to afford an oil, which crystallized upon adding some drops of petroleum ether: yield $86 \%$; mp $126-127{ }^{\circ} \mathrm{C}$ (petroleum ether); ${ }^{1} \mathrm{H}$ NMR $\delta 6.28(\mathrm{~s}, 1 \mathrm{H}, \mathrm{Ar} \mathrm{H}), 4.66(\mathrm{~s}, 2 \mathrm{H}$, $\left.\mathrm{CH}_{2} \mathrm{O}\right), 2.0-1.3\left(\mathrm{~m}, 20 \mathrm{H}, \mathrm{CH}_{2}\right) ;{ }^{13} \mathrm{C} \mathrm{NMR}^{52} \delta 140.1$ and $138.4(\mathrm{~s}$, C-3'a and C-8'a), 118.9 (s, C-4'), 107.0 (s, C-1), 92.2 (d, C-8'), 55.9 (t, $\left.\mathrm{CH}_{2} \mathrm{O}\right), 34.9(\mathrm{t}, \mathrm{C}-2), 24.6$ (t, C-4), 23.3 (t, C-3); mass spectrum, $m / e 332.161\left(\mathbf{M}^{+}\right.$, calcd 332.163).

Anal. Calcd for $\mathrm{C}_{19} \mathrm{H}_{24} \mathrm{O}_{5}$ ( $\left.M_{\mathrm{r}} 332.398\right)$ : C, 68.66; $\mathrm{H}, 7.28$. Found: C, 68.52; $\mathrm{H}, 7.29$.

$4^{\prime}$-(Chloromethyl)dispiro[cyclohexane-1,2' - benzo[ 1,2 $\left.d: 4,5-d^{\prime}\right]$ bis $[1,3]$ dioxole- $6^{\prime}, 1^{\prime \prime}$-cyclohexane] (10). A solution of $9(2.23 \mathrm{~g}, 6.7 \mathrm{mmol})$ and $(n-\mathrm{Bu})_{3} \mathrm{P}(2.71 \mathrm{~g}, 13.4 \mathrm{mmol})$ in $\mathrm{CCl}_{4}$ $(100 \mathrm{~mL})$ was refluxed for $24 \mathrm{~h}$, whereupon another portion of $(n-\mathrm{Bu})_{3} \mathrm{P}(1.00 \mathrm{~g}, 5.0 \mathrm{mmol})$ was added slowly at room temperature and refluxing was continued for $48 \mathrm{~h}$. After cooling to room temperature, water $(75 \mathrm{~mL})$ was added and the mixture was stirred overnight. Subsequently, the layers were separated, and the organic layer was dried with $\mathrm{MgSO}_{4}$ and passed through a short column of silica gel, using an additional $200 \mathrm{~mL}$ of $\mathrm{CHCl}_{3}$. After evaporation of the solvent the resulting solid was triturated with $\mathrm{MeOH}$ to give pure 10 : vield $95 \% ; \mathrm{mp} 122-124{ }^{\circ} \mathrm{C}(\mathrm{MeOH}) ;{ }^{1} \mathrm{H}$ NMR $\delta 6.31(\mathrm{~s}, 1 \mathrm{H}, \mathrm{Ar} \mathrm{H}), 4.54\left(\mathrm{~s}, 2 \mathrm{H}, \mathrm{CH}_{2} \mathrm{Cl}\right), 2.1-1.3(\mathrm{~m}, 20$ $\left.\mathrm{H}, \mathrm{CH}_{2}\right) ;{ }^{13} \mathrm{C} \mathrm{NMR}^{52} \delta 140.1$ and 139.1 (s, C-3'a and C-8'a), 119.3 (s, C-4' $), 103.9$ (s, C-1), $93.2\left(\mathrm{~d}, \mathrm{C}-8^{\prime}\right), 35.3\left(\mathrm{t}, \mathrm{CH}_{2} \mathrm{Cl}\right), 34.9(\mathrm{t}, \mathrm{C}-2)$, $24.6(\mathrm{t}, \mathrm{C}-4), 23.2(\mathrm{t}, \mathrm{C}-3)$; mass spectrum, $m / e 350.129\left(\mathrm{M}^{+}\right.$, calcd 350.129).

Anal. Calcd for $\mathrm{C}_{19} \mathrm{H}_{23} \mathrm{ClO}_{4}\left(M_{\mathrm{r}} 350.844\right)$ : C, 65.05; $\mathrm{H}, 6.61$. Found: C, 65.21; $\mathrm{H}, 6.68$.

Dispiro[cyclohexane-1,2'-ben zo[1,2-d:4,5-d']bis[1,3]dioxole- $6^{\prime}, 1^{\prime \prime}$-cyclohexane]-4'-acetonitrile (11). A mixture of 10 $(1.43 \mathrm{~g}, 4.1 \mathrm{mmol}), \mathrm{KCN}(1.33 \mathrm{~g}, 20.4 \mathrm{mmol})$, and 18 -crown-6 (0.40 $\mathrm{g}, 1.9 \mathrm{mmol})$ in acetonitrile $(50 \mathrm{~mL})$ was refluxed for $5 \mathrm{~h}$. After cooling to room temperature, the salts were filtered off, and the filtrate was concentrated. The residue was taken up in $\mathrm{CHCl}_{3}$ $(150 \mathrm{~mL})$ and washed with water $(2 \times 100 \mathrm{~mL})$. After drying the organic layer with $\mathrm{MgSO}_{4}$ and evaporation of the solvent 11 was obtained in a quantitative yield: $\mathrm{mp} 124-126{ }^{\circ} \mathrm{C}(\mathrm{MeOH}) ;{ }^{1} \mathrm{H}$

(52) The bisketals 8-12 are symmetrical, therefore we have assigned the absorptions in the ${ }^{13} \mathrm{C}$ NMR spectrum to only one carbon atom. 
NMR $\delta 6.30(\mathrm{~s}, 1 \mathrm{H}, \mathrm{Ar} \mathrm{H}), 3.56\left(\mathrm{~s}, 2 \mathrm{H}, \mathrm{CH}_{2} \mathrm{CN}\right), 2.1-1.3(\mathrm{~m}, 20$ $\left.\mathrm{H}, \mathrm{CH}_{2}\right) ;{ }^{13} \mathrm{C} \mathrm{NMR}^{52} \delta 140.2$ and $138.8\left(\mathrm{~s}, \mathrm{C}-3^{\prime} \mathrm{a}\right.$ and $\left.\mathrm{C}-8^{\prime} \mathrm{a}\right), 119.6$ and $116.4\left(\mathrm{~s}, \mathrm{C}-4^{\prime}\right.$ and $\mathrm{CN}$ ), $95.7(\mathrm{~s}, \mathrm{C}-1), 92.8\left(\mathrm{~d}, \mathrm{C}-8^{\prime}\right), 34.9(\mathrm{t}$, $\mathrm{C}-2), 24.6(\mathrm{t}, \mathrm{C}-4), 23.2(\mathrm{t}, \mathrm{C}-3), 12.8\left(\mathrm{t}, \mathrm{CH}_{2} \mathrm{CN}\right)$; IR (KBr) 2260 (CN) $\mathrm{cm}^{-1}$; mass spectrum, $\mathrm{m} / e 341.165\left(\mathrm{M}^{+}\right.$, calcd 341.163$)$.

Anal. Calcd for $\mathrm{C}_{20} \mathrm{H}_{23} \mathrm{NO}_{4}\left(M_{\mathrm{r}} 341.408\right)$ : C, 70.36; H, 6.79; $\mathrm{N}, 4.10$. Found: $\mathrm{C}, 70.48 ; \mathrm{H}, 6.89 ; \mathrm{N}, 3.92$.

$(E, Z)-\alpha-($ Phenylmethylene $)$ dispiro [cyclohexane-1,2' benzo[1,2-d:4,5-d $\left.d^{\prime}\right]$ bis [1,3] dioxole- $6^{\prime}, 1^{\prime \prime}$-cyclohexane $]-4^{\prime}$ acetonitrile (12). Cyanide $11(0.60 \mathrm{~g}, 1.8 \mathrm{mmol})$ was added to a solution of sodium methoxide $(0.13 \mathrm{~g} \mathrm{Na}, 5.7 \mathrm{mmol})$ in $\mathrm{MeOH}$ $(30 \mathrm{~mL})$. After the reaction mixture was heated for $35 \mathrm{~min}$ at $40-50^{\circ} \mathrm{C}$, freshly distilled benzaldehyde $(0.56 \mathrm{~g}, 5.3 \mathrm{mmol})$ was added and the solution was refluxed for $7 \mathrm{~h}$. After cooling to 0 ${ }^{\circ} \mathrm{C}$ the precipitate was filtered off to afford one isomer of 12 in a yield of $77 \%$. The filtrate was concentrated to $10 \mathrm{~mL}, \mathrm{CHCl}_{3}$ (30 mL) was added, and the resulting solution was washed thoroughly with a $15 \% \mathrm{NaHSO}_{3}$ solution $(3 \times 75 \mathrm{~mL}), \mathrm{NaHCO}_{3}$ solution $(75 \mathrm{~mL})$, and water $(75 \mathrm{~mL})$. After drying with $\mathrm{MgSO}_{4}$ and removal of the solvent the resulting crude compound was purified by chromatography $\left(\mathrm{CHCl}_{3}\right.$ :petroleum ether $\left.=3: 1\right)$ to give a mixture of $E / Z$ isomers as an oil in $8 \%$ yield. Only the data of the major isomer are given.

Major isomer: $\mathrm{mp} 171-172^{\circ} \mathrm{C}(\mathrm{MeOH}) ;{ }^{1} \mathrm{H}$ NMR $\delta 8.0-7.8$ and 7.6-7.4 (m, $5 \mathrm{H}, \mathrm{Ph} \mathrm{H}), 7.70$ (s, $1 \mathrm{H},=\mathrm{CH}), 6.36$ (s, $1 \mathrm{H}, \mathrm{H}-8^{\prime}$ ), 2.1-1.3 (m, $\left.20 \mathrm{H}, \mathrm{CH}_{2}\right) ;{ }^{13} \mathrm{C} \mathrm{NMR}^{52} \delta 146.5(\mathrm{~d},=\mathrm{CH}), 140.7$ and 137.8 (s, C-3'a and C-8'a), 119.5 and 116.7 (s, C-4' and CN), 103.1 and $102.5[\mathrm{~s}, \mathrm{C}-1$ and $=C(\mathrm{CN})], 93.4\left(\mathrm{~d}, \mathrm{C}-8^{\prime}\right), 34.9(\mathrm{t}, \mathrm{C}-2), 24.6$ $(\mathrm{t}, \mathrm{C}-4), 23.3(\mathrm{t}, \mathrm{C}-3)$; IR (KBr) $2210(\mathrm{CN}) \mathrm{cm}^{-1}$; mass spectrum, $m / e 429.190\left(\mathrm{M}^{+}\right.$, calcd 429.194).

Anal. Calcd for $\mathrm{C}_{27} \mathrm{H}_{27} \mathrm{NO}_{4}\left(M_{\mathrm{r}} 429.517\right)$ : C, 75.50; $\mathrm{H}, 6.34$; N, 3.26. Found: C, 75.64; H, 6.35; N, 3.16.

$(E, Z)-2,5$-Dimethoxy-3,6-dioxo- $\alpha$-(phenylmethylene)-1,4cyclohexadiene-1-acetonitrile (14). To a solution of $12(0.40$ g, $0.9 \mathrm{mmol})$ in $\mathrm{CH}_{2} \mathrm{Cl}_{2}(20 \mathrm{~mL})$ was added a solution of $\mathrm{BBr}_{3}(2.39$ g, $9.3 \mathrm{mmol})$ in $\mathrm{CH}_{2} \mathrm{Cl}_{2}(10 \mathrm{~mL})$ at $0{ }^{\circ} \mathrm{C}$. After stirring for 1.5 $\mathrm{h}$ at $0^{\circ} \mathrm{C}$, water $(30 \mathrm{~mL})$ was slowly added at such a rate that the temperature did not rise above $25^{\circ} \mathrm{C}$. Subsequently, the $\mathrm{pH}$ of the water layer was set to 9 by adding a $2 \mathrm{M} \mathrm{NaOH}$ solution and the mixture was stirred in open air for $1.5 \mathrm{~h}$, followed by the addition of a $4 \mathrm{M} \mathrm{HCl}$ solution to adjust the $\mathrm{pH}$ to 1 . The layers were separated and the water layer was extracted with $\mathrm{CH}_{2} \mathrm{Cl}_{2}$ $(6 \times 40 \mathrm{~mL})$. The combined organic layers were dried $\left(\mathrm{MgSO}_{4}\right)$ and the solvent was evaporated to afford crude 13 , which was used without purification: ${ }^{1} \mathrm{H}$ NMR (DMSO- $\left.d_{6}\right) \delta 9.3(\mathrm{br} \mathrm{s}, 2 \mathrm{H}, \mathrm{OH}$ ) 7.9-7.2 (m, $6 \mathrm{H},=\mathrm{CH}$ and $\mathrm{PhH}), 5.80(\mathrm{~s}, 1 \mathrm{H}, \mathrm{H}-4)$; mass spectrum, $m / e 267.052\left(\mathrm{M}^{+}\right.$, calcd for $\left.\mathrm{C}_{15} \mathrm{H}_{9} \mathrm{NO}_{4} 267.053\right)$.

To a solution of crude 13 in $\mathrm{CH}_{2} \mathrm{Cl}_{2}(50 \mathrm{~mL})$ was added a solution of $\mathrm{CH}_{2} \mathrm{~N}_{2}(2.0 \mathrm{mmol})$ in $\mathrm{Et}_{2} \mathrm{O}(6 \mathrm{~mL})$ and the whole was stirred for $5 \mathrm{~min}$. Subsequently, acetic acid was added to destroy the excess of $\mathrm{CH}_{2} \mathrm{~N}_{2}$, whereupon the resulting solution was washed with a $\mathrm{NaHCO}_{3}$ solution $(50 \mathrm{~mL})$ and water $(50 \mathrm{~mL})$. After drying with $\mathrm{MgSO}_{4}$ and removal of the solvent the resulting crude compound was purified by chromatography (EtOAc) to give 14 as a mixture of $E / Z$ isomers as an oil in a yield of $55 \%$ (from 12 ) ${ }^{1} \mathrm{H}$ NMR $\delta 7.9-7.1(\mathrm{~m}, 6 \mathrm{H}, \mathrm{PhH}$ and $=\mathrm{CH}$ of the major isomer), $6.99(\mathrm{~s}, 1 \mathrm{H},=\mathrm{CH}), 5.83(\mathrm{~s}, 1 \mathrm{H}, \mathrm{H}-4), 4.22,4.00,3.83$, and 3.61 (s, $\left.3 \mathrm{H}, \mathrm{OCH}_{3}\right)$; IR (KBr) 2210 and $2200(\mathrm{CN}) \mathrm{cm}^{-1}$; mass spectrum, $m / e 295.085\left(\mathrm{M}^{+}\right.$, calcd for $\left.\mathrm{C}_{17} \mathrm{H}_{13} \mathrm{NO}_{4} 295.084\right)$.

General Procedure for the Synthesis of the (Dialkylamino)benzoquinones $15-17$. To a solution of $14(1.00 \mathrm{~g}, 3.4$ $\mathrm{mmol})$ in $\mathrm{MeOH}(80 \mathrm{~mL})$ was added the amine $(10.2 \mathrm{mmol})$ at room temperature and stirring was continued for $1.5 \mathrm{~h}$. In the case of 15 the precipitate was filtered off and washed with $\mathrm{MeOH}$ to give one pure isomer in a yield of $57 \%$, while the filtrate was evaporated and subjected to chromatography (EtOAc) to afford an oil containing a 1:1 mixture of $E / Z$ isomers in a yield of $38 \%$. In the case of the dipiperidinyl quinone 16 and the dimorpholinyl quinone 17 the solvent and excess amine were evaporated, and the residue was subsequently purified by chromatography (Et$\mathrm{OAc}$.

$(E)$ - or $(Z)-3,6$-Dioxo- $\alpha$-(phenylmethylene)-2,5-di(1pyrrolidinyl)-1,4-cyclohexadiene-1-acetonitrile (15). Major isomer: $\mathrm{mp} 175-176^{\circ} \mathrm{C}(\mathrm{EtOH}) ;{ }^{1} \mathrm{H}$ NMR $\delta 7.9-7.8$ and $7.6-7.3$ (m, $5 \mathrm{H}, \mathrm{Ph} \mathrm{H}), 6.74(\mathrm{~s}, 1 \mathrm{H}=\mathrm{CH}), 5.32(\mathrm{~s}, 1 \mathrm{H}, \mathrm{H}-4), 4.2-3.0$ , $\left.8 \mathrm{H}, \mathrm{NCH}_{2}\right), 2.1-1.7\left(\mathrm{~m}, 8 \mathrm{H}, \mathrm{CH}_{2}\right) ;{ }^{13} \mathrm{C}$ NMR $\delta 181.2(\mathrm{~s}, \mathrm{C}=\mathrm{O})$,
151.8 and $149.8(\mathrm{~s}, \mathrm{C}-2$ and $\mathrm{C}-5), 145.8(\mathrm{~d},=\mathrm{CH}), 118.6(\mathrm{~s}, \mathrm{CN})$, $107.1[\mathrm{~s},=C(\mathrm{CN})], 98.4(\mathrm{~d}, \mathrm{C}-4), 54.8\left(\mathrm{t}, \mathrm{NCH}_{2}\right), 25.4\left(\mathrm{t}, \mathrm{CH}_{2}\right)$; IR $(\mathrm{KBr}) 2200(\mathrm{CN}), 1615(\mathrm{C}=\mathrm{O}) \mathrm{cm}^{-1}$; mass spectrum, m/e $373.178\left(\mathrm{M}^{+}\right.$, calcd 373.179)

Anal. Calcd for $\mathrm{C}_{23} \mathrm{H}_{23} \mathrm{~N}_{3} \mathrm{O}_{2}\left(M_{\mathrm{r}} 373.456\right)$ : C, 73.97; $\mathrm{H}, 6.21$; $\mathrm{N}, 11.25$. Found: C, $73.95 ; \mathrm{H}, 6.14 ; \mathrm{N}, 11.26$.

$(E, Z)-3,6-D i o x o-\alpha-($ h henylmethylene $)-2,5-d i(1-$ piperidinyl)-1,4-cyclohexadiene-1-acetonitrile (16): yield $93 \%$; oil; isomer ratio $=7: 3 ;{ }^{1} \mathrm{H}$ NMR $\delta 8.0-7.7$ and $7.6-7.2(\mathrm{~m}, 5 \mathrm{H}$, $\mathrm{Ph} \mathrm{H}), 6.98$ and $6.92(\mathrm{~s}, 1 \mathrm{H},=\mathrm{CH}), 5.61$ and $5.55(\mathrm{~s}, 1 \mathrm{H}, \mathrm{H}-4)$, 3.8-3.2 (m, $\left.8 \mathrm{H}, \mathrm{NCH}_{2}\right), 2.0-1.2\left(\mathrm{~m}, 12 \mathrm{H}, \mathrm{CH}_{2}\right)$; IR (KBr) 2230 and $2210(\mathrm{CN}), 1630(\mathrm{C}=0) \mathrm{cm}^{-1}$; mass spectrum, $m / e 401.212$ $\left(\mathrm{M}^{+}\right.$, calcd for $\left.\mathrm{C}_{25} \mathrm{H}_{27} \mathrm{~N}_{3} \mathrm{O}_{2} 401.210\right)$.

(E,Z)-3,6-Dioxo-2,5-di(4-morpholinyl)- $\alpha$-(phenylmethylene)-1,4-cyclohexadiene-1-acetonitrile (17): yield $91 \%$; oil; isomer ratio $=2: 1 ;{ }^{1} \mathrm{H}$ NMR $\delta 7.9-7.75$ and $7.7-7.1(\mathrm{~m}, 5 \mathrm{H}$, $\mathrm{Ph} \mathrm{H}), 7.19$ and $7.00(\mathrm{~s}, 1 \mathrm{H},=\mathrm{CH}), 5.82$ and $5.63(\mathrm{~s}, 1 \mathrm{H}, \mathrm{H}-4)$, $4.0-3.3\left(\mathrm{~m}, 16 \mathrm{H}, \mathrm{NCH}_{2}\right.$ and $\left.\mathrm{OCH}_{2}\right)$; IR $(\mathrm{KBr}) 2220(\mathrm{CN}), 1630$ $(\mathrm{C}=0) \mathrm{cm}^{-1}$; mass spectrum, $m / e 405.165\left(\mathrm{M}^{+}\right.$, calcd for $\mathrm{C}_{25^{-}}$ $\mathrm{H}_{27} \mathrm{~N}_{3} \mathrm{O}_{2} 405.169$ ).

$(E, Z)-2,5$-Dimethoxy- $\alpha$-(phenylmethylene)-3,6-di(1pyrrolidinyl- and 1-piperidinyl) benzeneacetonitrile (18 and 19). Hydrogen was bubbled through a solution of $15 / 16(0.6$ $\mathrm{mmol})$ in dry DMF $(20 \mathrm{~mL})$ to which was added $5 \% \mathrm{Pd} / \mathrm{C}(0.10$ g) until the solution was colorless $(1.5 \mathrm{~h})$. Then $\mathrm{Ba}(\mathrm{OH})_{2} \cdot 8 \mathrm{H}_{2} \mathrm{O}$ $(0.92 \mathrm{~g}, 3.0 \mathrm{mmol})$ and dimethyl sulfate $(0.37 \mathrm{~g}, 3.0 \mathrm{mmol})$ were added and slow hydrogen bubbling was continued for $24 \mathrm{~h}$. Subsequently, EtOAc $(50 \mathrm{~mL})$ was added and the reaction mixture was filtered through hyflo. The hyflo was eluted with EtOAc (150 $\mathrm{mL}$ ) and the combined organic layers were washed with a $\mathrm{NH}_{4} \mathrm{Cl}$ solution $(6 \times 100 \mathrm{~mL})$. Drying $\left(\mathrm{MgSO}_{4}\right)$ and evaporation of the solvent gave the methylated hydroquinones.

18: yield 50\%; oil; isomer ratio $=2: 1 ;{ }^{1} \mathrm{H}$ NMR $\delta 8.0-7.8$ and 7.5-7.1 (m, $6 \mathrm{H},=\mathrm{CH}$ and $\mathrm{Ph} \mathrm{H}), 6.39$ and $6.34(\mathrm{~s}, 1 \mathrm{H}, \mathrm{H}-4)$, $3.80,3.56$, and $3.51\left(\mathrm{~s}, 3 \mathrm{H}, 6 \mathrm{H}\right.$, and $3 \mathrm{H}$, respectively, $\left.\mathrm{OCH}_{3}\right)$, 3.5-3.0 (m, $\left.8 \mathrm{H}, \mathrm{NCH}_{2}\right), 2.0-1.8\left(\mathrm{~m}, 8 \mathrm{H}, \mathrm{CH}_{2}\right)$; IR (KBr) 2220 and $2210(\mathrm{CN}) \mathrm{cm}^{-1}$; mass spectrum, $\mathrm{m} / \mathrm{e} 403.228\left(\mathrm{M}^{+}\right.$, calcd for $\mathrm{C}_{25} \mathrm{H}_{29} \mathrm{~N}_{3} \mathrm{O}_{2} 403.226$ )

In the case of 19 only one isomer was obtained after trituration with diisopropyl ether: yield $49 \%$; mp $146-147^{\circ} \mathrm{C}$ (diisopropyl ether); ${ }^{1} \mathrm{H}$ NMR $\delta 7.28(\mathrm{~s}, 6 \mathrm{H},=\mathrm{CH}$ and $\mathrm{Ph} \mathrm{H}), 6.51(\mathrm{~s}, 1 \mathrm{H}, \mathrm{H}-4)$, 4.02 and $3.81\left(\mathrm{~s}, 3 \mathrm{H}, \mathrm{OCH}_{3}\right), 3.5-2.65\left(\mathrm{~m}, 8 \mathrm{H}, \mathrm{NCH}_{2}\right), 2.0-1.4$ $\left(\mathrm{m}, 12 \mathrm{H}, \mathrm{CH}_{2}\right) ;{ }^{13} \mathrm{C}$ NMR $\delta 155.4(\mathrm{~d},=\mathrm{CH}), 144.2,144.1,138.3$, and 133.4 (s, C-2, C-3, C-5, and C-6), 118.8 (s, CN), 103.2 (d, C-4), 58.7 and $55.4\left(\mathrm{q}, \mathrm{OCH}_{3}\right), 51.8$ and $51.6\left(\mathrm{t}, \mathrm{NCH}_{2}\right)$; IR (KBr) 2210 (CN) $\mathrm{cm}^{-1}$; mass spectrum, $m / e 433.272\left(\mathrm{M}^{+}\right.$, calcd 433.273).

Anal. Calcd for $\mathrm{C}_{27} \mathrm{H}_{35} \mathrm{~N}_{3} \mathrm{O}_{2}\left(M_{\mathrm{r}} 433.596\right)$ : $\mathrm{C}, 74.79 ; \mathrm{H}, 8.14$; N, 9.69. Found: C, $74.90 ; \mathrm{H}, 8.09 ; \mathrm{N}, 9.63$.

3-Bromo-1,4-dimethoxy-2-naphthaleneacetonitrile (21) was prepared starting from $20(3.60 \mathrm{~g}, 10.0 \mathrm{mmol})$ analogously to 11 and purified by flash chromatography (petroleum ether:EtOAc $=3: 1):$ yield $77 \% ; \mathrm{mp} 112-114^{\circ} \mathrm{C}(\mathrm{MeOH}) ;{ }^{1} \mathrm{H}$ NMR $\delta 8.2-8.0$ and 7.7-7.5 (m, $4 \mathrm{H}, \mathrm{Ar} \mathrm{H}), 4.08\left(\mathrm{~s}, 2 \mathrm{H}, \mathrm{CH}_{2} \mathrm{CN}\right), 4.03$ and 4.00 (s, $\left.3 \mathrm{H}, \mathrm{OCH}_{3}\right) ;{ }^{13} \mathrm{C}$ NMR $\delta 151.6$ and $150.8(\mathrm{~s}, \mathrm{C}-1$ and $\mathrm{C}-4), 117.2$ (s, CN), 63.0 and $61.5\left(\mathrm{q}, \mathrm{OCH}_{3}\right), 19.1\left(\mathrm{t}, \mathrm{CH}_{2} \mathrm{CN}\right)$; IR (KBr) 2240 (CN) $\mathrm{cm}^{-1}$; mass spectrum, $\mathrm{m} / e 305.004\left(\mathrm{M}^{+}\right.$, calcd 305.005).

Anal. Calcd for $\mathrm{C}_{14} \mathrm{H}_{12} \mathrm{BrNO}_{2}\left(M_{\mathrm{r}} 306.159\right)$ : C, $54.92 ; \mathrm{H}, 3.95$; $\mathrm{N}$, 4.58. Found: C, $54.66 ; \mathrm{H}, 3.89 ; \mathrm{N}, 4.49$.

$(E, Z)$-3-Bromo-1,4-dimethoxy- $\alpha$-(phenylmethylene)-2naphthaleneacetonitrile (22) was prepared starting from 21 $(3.06 \mathrm{~g}, 10.0 \mathrm{mmol})$ analogously to 12 and purified by chromatography $\left(\mathrm{CH}_{2} \mathrm{Cl}_{2}\right.$ :petroleum ether $\left.=3: 1\right)$ to give one isomer as a solid and the other as an oil (in a ratio of $5: 4$ ) in a total yield of $81 \%$.

Solid isomer: $\mathrm{mp} 139-140^{\circ} \mathrm{C}(\mathrm{MeOH}) ;{ }^{1} \mathrm{H}$ NMR $\delta 8.25-7.9$ and 7.7-7.3 (m, $9 \mathrm{H}, \mathrm{Ar} \mathrm{H}$ and $\mathrm{Ph} \mathrm{H}), 7.21(\mathrm{~s}, 1 \mathrm{H},=\mathrm{CH}), 4.02$ and $3.96\left(\mathrm{~s}, 3 \mathrm{H}, \mathrm{OCH}_{3}\right) ;{ }^{13} \mathrm{C}$ NMR $\delta 151.9$ and 150.6 (s, C- 1 and $\mathrm{C}-4), 149.6(\mathrm{~d},=\mathrm{CH}), 117.7$ (s, $\mathrm{CN}), 62.4$ and $61.5\left(\mathrm{q}, \mathrm{OCH}_{3}\right)$; IR (KBr) $2205(\mathrm{CN}) \mathrm{cm}^{-1}$; mass spectrum, $m / e 393.035\left(\mathrm{M}^{+}\right.$, calcd 393.037).

Anal. Calcd for $\mathrm{C}_{21} \mathrm{H}_{16} \mathrm{BrNO}_{2}\left(M_{\tau} 394.268\right): \mathrm{C}, 63.97 ; \mathrm{H}, 4.09$; $\mathrm{N}, 3.55$. Found: C, $63.71 ; \mathrm{H}, 4.04 ; \mathrm{N}, 3.73$.

Minor isomer: oil; ${ }^{1} \mathrm{H}$ NMR $88.25-8.05$ and $7.7-7.5(\mathrm{~m}, 4 \mathrm{H}$ Ar H), 7.56 (s, $1 \mathrm{H},=\mathrm{CH}), 7.25-7.0(\mathrm{~m}, 5 \mathrm{H}, \mathrm{Ph} \mathrm{H}), 3.99$ and 3.91 (s, $\left.3 \mathrm{H}, \mathrm{OCH}_{3}\right) ;{ }^{13} \mathrm{C}$ NMR $\delta 151.6$ and $151.2(\mathrm{~s}, \mathrm{C}-1$ and $\mathrm{C}-4), 147.5$ $(\mathrm{d},=\mathrm{CH}), 119.3(\mathrm{~s}, \mathrm{CN}), 62.5$ and $61.6\left(\mathrm{q}, \mathrm{OCH}_{3}\right) ; \mathrm{IR}(\mathrm{KBr}) 2210$ 
(CN) $\mathrm{cm}^{-1}$; mass spectrum, $m / e 393.035\left(\mathrm{M}^{+}\right.$, calcd for $\mathrm{C}_{21} \mathrm{H}_{16^{-}}$ $\mathrm{BrNO}_{2}$ 393.037).

Sodium Salt of 3-Bromo- $\alpha$-(hydroxymethylene)-1,4-dimethoxy-2-naphthaleneacetonitrile (23). To a suspension of $80 \% \mathrm{NaH}(0.36 \mathrm{~g}, 12.0 \mathrm{mmol})$ in toluene $(50 \mathrm{~mL})$ was added 21 $(3.06 \mathrm{~g}, 10.0 \mathrm{mmol})$ at room temperature. Heating of the reaction mixture for $2 \mathrm{~h}$ at $110^{\circ} \mathrm{C}$ resulted in the formation of a grey precipitate. Upon cooling to $50^{\circ} \mathrm{C}$ ethyl formate $(3.3 \mathrm{~mL}, 40.0$ $\mathrm{mmol}$ ) was added dropwise, whereupon the reaction mixture was heated at that temperature for $15 \mathrm{~h}$. Upon cooling 23 precipitated was filtered off, and was washed with dry diethyl ether $(3 \times 50$ $\mathrm{mL}$ ) to give the sodium salt of 23 in a yield of $84 \%$.

$(E)$ - or (Z)-3-Bromo-1,4-dimethoxy- $\alpha$-[[[ (4-methylphenyl)sulfonyl ]oxy]methylene]-2-naphthaleneacetonitrile (24) and $(E / Z)$-3-Bromo-1,4-dimethoxy- $\alpha$-[(phenylthio)methylene]-2-naphthaleneacetonitrile (25). To a suspension of the sodium salt of 23 ( $2.41 \mathrm{~g}, 6.8 \mathrm{mmol})$ in THF $(150 \mathrm{~mL})$ and water $(10 \mathrm{~mL})$ was added concentrated sulfuric acid $(3 \mathrm{~mL})$. After stirring for $10 \mathrm{~min}$, water $(100 \mathrm{~mL})$ was added to the reaction mixture. Compound 23 was isolated by extraction with $\mathrm{CHCl}_{3}$ $(3 \times 150 \mathrm{~mL})$. The combined extracts were washed with water $(3 \times 100 \mathrm{~mL})$ and dried with $\mathrm{MgSO}_{4}$. Removal of the solvent under reduced pressure gave 23 as an oil in quantitative yield, which was used without purification. To a solution of $\mathbf{2 3}(2.26$ $\mathrm{g}, 6.8 \mathrm{mmol})$ in pyridine $(15 \mathrm{~mL})$ was added tosyl chloride $(1.33$ $\mathrm{g}, 7.0 \mathrm{mmol}$ ) at $0^{\circ} \mathrm{C}$. Stirring was continued for $30 \mathrm{~min}$ at this temperature, whereupon thiophenol $(0.7 \mathrm{~mL}, 7.0 \mathrm{mmol})$ was added. After stirring for $48 \mathrm{~h}$ at room temperature the solution was poured into $1 \% \mathrm{NaOH}(50 \mathrm{~mL})$ and extracted with $\mathrm{Et}_{2} \mathrm{O}(4$ $\times 75 \mathrm{~mL}$ ). The combined organic layers were washed with water $(100 \mathrm{~mL}), 25 \% \mathrm{KOH}(100 \mathrm{~mL})$, and water $(100 \mathrm{~mL})$ and dried with $\mathrm{MgSO}_{4}$. Evaporation of the solvent gave an oil which was subjected to chromatography (petroleum ether:EtOAc $=3: 1$ ) to afford $25(70 \%)$ and $24(5 \%)$.

24: $\mathrm{mp} 132-134{ }^{\circ} \mathrm{C}\left(\mathrm{CCl}_{4}\right) ;{ }^{1} \mathrm{H}$ NMR $\delta 8.2-7.9$ and $7.8-7.25(\mathrm{~m}$, $9 \mathrm{H}, \mathrm{Ar} \mathrm{H}$, TosH, and $=\mathrm{CH}), 3.93$ and $3.78\left(\mathrm{~s}, 3 \mathrm{H}, \mathrm{OCH}_{3}\right), 2.47$ (s, $3 \mathrm{H}, \mathrm{CH}_{3}$ ); ${ }^{13} \mathrm{C}$ NMR $\delta 152.1$ and 150.6 (s, C-1 and $\left.\mathrm{C}-4\right), 149.2$ $(\mathrm{d},=\mathrm{CH}), 118.8(\mathrm{~s}, \mathrm{CN}), 62.5$ and $61.5\left(\mathrm{q}, \mathrm{OCH}_{3}\right), 21.8\left(\mathrm{q}, \mathrm{CH}_{3}\right)$; IR $(\mathrm{KBr}) 2210(\mathrm{CN}), 1350$ and $1180\left(\mathrm{OSO}_{2}\right) \mathrm{cm}^{-1}$; mass spectrum, $m / e 487.010\left(\mathrm{M}^{+}\right.$, calcd 487.009).

Anal. Calcd for $\mathrm{C}_{22} \mathrm{H}_{18} \mathrm{BrNO}_{5} \mathrm{~S}\left(M_{\mathrm{r}} 488.356\right): \mathrm{C}, 54.11 ; \mathrm{H}, 3.72$; N, 2.87. Found: C, 53.97; H, 3.70; N, 2.79.

25: oil; isomer ratio $=1: 1 ;{ }^{1} \mathrm{H}$ NMR $\delta 8.25-8.0$ and $7.75-7.2$ $(\mathrm{m}, 10 \mathrm{H}, \mathrm{Ar} \mathrm{H}, \mathrm{Ph} \mathrm{H}$, and $=\mathrm{CH}), 4.03,3.98$, and $3.95(\mathrm{~s}, 3 \mathrm{H}$, $6 \mathrm{H}$, and $3 \mathrm{H}$, respectively, $\left.\mathrm{OCH}_{3}\right)$; IR (KBr) 2250 and $2210(\mathrm{CN})$ $\mathrm{cm}^{-1}$; mass spectrum, $m / e 425.004\left(\mathrm{M}^{+}\right.$, calcd for $\mathrm{C}_{21} \mathrm{H}_{16} \mathrm{BrNO}_{2} \mathrm{~S}$ 425.009).

General Procedure for the Synthesis of the Ketene Dithioacetals 26 and 27 . To a suspension of $\mathrm{KO}-t-\mathrm{Bu}(6.16 \mathrm{~g}, 55.0$ $\mathrm{mmol})$ in THF $(50 \mathrm{~mL})$ was added a solution of $21(8.00 \mathrm{~g}, 25.0$ $\mathrm{mmol})$ and $\mathrm{CS}_{2}(2.0 \mathrm{~mL}, 27.0 \mathrm{mmol})$ in THF $(70 \mathrm{~mL})$ over a period of $1 \mathrm{~h}$ at room temperature. After stirring for an additional hour at room temperature, the precipitate was filtered off and washed with $\mathrm{Et}_{2} \mathrm{O}(100 \mathrm{~mL})$. Subsequently, this dipotassium salt was dissolved in a mixture of $\mathrm{MeOH}(100 \mathrm{~mL})$ and water $(40 \mathrm{~mL})$, whereupon 1,3-dibromopropane or 1,2-dibromoethane $(27.0 \mathrm{mmol})$ was added and the resulting solution was refluxed for $2 \mathrm{~h}$. After cooling to room temperature $\mathrm{NH}_{4} \mathrm{Cl}(1.5 \mathrm{~g})$ was added and the mixture was extracted with EtOAc $(3 \times 150 \mathrm{~mL})$. The combined EtOAc layers were washed with a saturated $\mathrm{NaCl}$ solution (450 $\mathrm{mL}$ ) and dried with $\mathrm{MgSO}_{4}$. After removal of the solvent under reduced pressure, the residue was subjected to chromatography $\left(\mathrm{CH}_{2} \mathrm{Cl}_{2}\right)$ to give pure 26 and 27 .

3-Bromo-1,4-dimethoxy- $\alpha$-1,3-dithian-2-ylidene-2naphthaleneacetonitrile $(26)$ : yield $50 \% ; \mathrm{mp} 143-145{ }^{\circ} \mathrm{C}$ (EtOAc/MeOH); ${ }^{1} \mathrm{H}$ NMR $\delta 8.2-8.0$ and 7.7-7.5 (m, $4 \mathrm{H}, \mathrm{Ar} \mathrm{H}$ ), 3.99 and $3.96\left(\mathrm{~s}, 3 \mathrm{H}, \mathrm{OCH}_{3}\right), 3.3-2.8\left(\mathrm{~m}, 4 \mathrm{H}, \mathrm{SCH}_{2}\right), 2.4-2.0(\mathrm{~m}$, $\left.2 \mathrm{H}, \mathrm{CH}_{2}\right) ;{ }^{13} \mathrm{C}$ NMR $\delta 162.4\left(\mathrm{~s},=\mathrm{CS}_{2}\right), 152.5$ and $150.5(\mathrm{~s}, \mathrm{C}-1$ and $\mathrm{C}-4), 116.8(\mathrm{~s}, \mathrm{CN}), 62.8$ and $61.5\left(\mathrm{q}, \mathrm{OCH}_{3}\right), 29.0$ and 28.9 $\left(\mathrm{t}, \mathrm{SCH}_{2}\right), 22.9\left(\mathrm{t}, \mathrm{CH}_{2}\right) ; \mathrm{IR}(\mathrm{KBr}) 2200(\mathrm{CN}) \mathrm{cm}^{-1} ;$ mass spectrum, $m / e 420.978\left(\mathrm{M}^{+}\right.$, calcd 420.981$)$.

Anal. Calcd for $\mathrm{C}_{18} \mathrm{H}_{16} \mathrm{BrNO}_{2} \mathrm{~S}_{2}\left(M_{\mathrm{r}} 422.363\right)$ : $\mathrm{C}, 51.19 ; \mathrm{H}, 3.82$; $\mathrm{N}, 3.32$. Found: C, $51.30 ; \mathrm{H}, 3.70 ; \mathrm{N}, 3.25$.

3-Bromo-1,4-dimethoxy- $\alpha-1,3$-dithiolan-2-ylidene-2. naphthaleneacetonitrile (27): yield $61 \% ; \mathrm{mp} 152-154{ }^{\circ} \mathrm{C}$ (EtOAc/petroleum ether); ${ }^{1} \mathrm{H}$ NMR $\delta 8.2-8.0$ and $7.65-7.5(\mathrm{~m}$,
$4 \mathrm{H}, \mathrm{Ar} \mathrm{H}), 4.00$ and $3.99\left(\mathrm{~s}, 3 \mathrm{H}, \mathrm{OCH}_{3}\right), 3.7-3.4\left(\mathrm{~m}, 4 \mathrm{H}, \mathrm{SCH}_{2}\right)$; ${ }^{13} \mathrm{C}$ NMR $\delta 174.6\left(\mathrm{~s},=\mathrm{CS}_{2}\right), 152.1$ and $150.5(\mathrm{~s}, \mathrm{C}-1$ and $\mathrm{C}-4), 117.8$ (s, CN), 62.9 and $61.5\left(\mathrm{q}, \mathrm{OCH}_{3}\right), 39.7$ and $39.5\left(\mathrm{t}, \mathrm{SCH}_{2}\right)$; IR (KBr) $2200(\mathrm{CN}) \mathrm{cm}^{-1}$; mass spectrum, $m / e 406.966\left(\mathrm{M}^{+}\right.$, calcd 406.965$)$.

Anal. Calcd for $\mathrm{C}_{17} \mathrm{H}_{14} \mathrm{BrNO}_{2} \mathrm{~S}_{2}\left(M_{\mathrm{r}} 408.336\right): \mathrm{C}, 50.00 ; \mathrm{H}, 3.46$; $\mathrm{N}, 3.43$. Found: C, 49.90; H, 3.50; N, 3.39.

General Procedure for the Synthesis of the Bromo Quinones 28-31. To a solution of $22,25,26$, or $27(2.0 \mathrm{mmol})$ in a mixture of acetonitrile and water ( 54 and $6 \mathrm{~mL}$, respectively) was added a solution of CAN $(2.70 \mathrm{~g}, 5.0 \mathrm{mmol})$ in water $(7 \mathrm{~mL})$ at $0^{\circ} \mathrm{C}$ over a period of $30 \mathrm{~min}$. After being stirred for an additional $1.5 \mathrm{~h}$ at room temperature, the reaction mixture was poured into water $(200 \mathrm{~mL})$ and extracted with $\mathrm{CHCl}_{3}(3 \times 250 \mathrm{~mL})$. The combined extracts were washed with water $(3 \times 200 \mathrm{~mL})$ and dried with $\mathrm{MgSO}_{4}$. Removal of the solvent under reduced pressure gave the crude bromo quinones 28-31, which were purified by flash chromatography (petroleum ether:EtOAc $=3: 1$ ).

$(E)$ - or $(Z)$-3-Bromo-1,4-dihydro-1,4-dioxo- $\alpha$-(phenylmethylene)-2-naphthaleneacetonitrile (28) was obtained as a solid ${ }^{53}$ (starting from the solid isomer of 22 ): yield $65 \% ; \mathrm{mp}$ 156-158 ${ }^{\circ} \mathrm{C}(\mathrm{EtOH}) ;{ }^{1} \mathrm{H}$ NMR $\delta 8.2-8.1$ and 8.0-7.9 (m, $4 \mathrm{H}, \mathrm{Ar}$ $\mathrm{H}), 7.9-7.75$ and $7.6-7.45(\mathrm{~m}, 5 \mathrm{H}, \mathrm{Ph} \mathrm{H}), 7.28(\mathrm{~s}, 1 \mathrm{H},=\mathrm{CH})$; ${ }^{13} \mathrm{C}$ NMR $\delta 182.8$ and $178.9(\mathrm{~s}, \mathrm{C}=\mathrm{O}), 151.6(\mathrm{~d},=\mathrm{CH}), 117.7(\mathrm{~s}$, $\mathrm{CN})$; IR (KBr) $2210(\mathrm{CN}), 1680(\mathrm{C}=0) \mathrm{cm}^{-1}$; mass spectrum, $m / e$ $362.990\left(\mathrm{M}^{+}\right.$, calcd for $\left.\mathrm{C}_{19} \mathrm{H}_{10} \mathrm{BrNO}_{2} 362.990\right)$.

The other isomer of 28 was obtained as an oil (starting from the other isomer of 22): yield $65 \%$; ${ }^{1} \mathrm{H}$ NMR $\delta 8.4-8.0$ and $7.95-7.7$ (m, $4 \mathrm{H}, \mathrm{Ar} \mathrm{H}), 7.66(\mathrm{~s}, 1 \mathrm{H},=\mathrm{CH}), 7.6-7.1(\mathrm{~m}, 5 \mathrm{H}, \mathrm{Ph} \mathrm{H}) ;{ }^{13} \mathrm{C}$ NMR $\delta 181.5$ and $178.0(\mathrm{~s}, \mathrm{C}=0), 150.0(\mathrm{~d},=\mathrm{CH}), 116.8(\mathrm{~s}, \mathrm{CN})$; IR $(\mathrm{KBr}) 2210(\mathrm{CN}), 1680(\mathrm{C}=0) \mathrm{cm}^{-1}$; mass spectrum, $m / e$ $362.990\left(\mathrm{M}^{+}\right.$, calcd for $\left.\mathrm{C}_{19} \mathrm{H}_{10} \mathrm{BrNO}_{2} 362.990\right)$.

$(E / Z)$-3-Bromo-1,4-dihydro-1,4-dioxo- $\alpha$-[(phenylthio)methylene]-2-naphthaleneacetonitrile (29): yield $48 \%$; oil; isomer ratio $=1: 1 ;{ }^{1} \mathrm{H}$ NMR $\delta 8.25-8.0$ and $7.9-7.25(\mathrm{~m}, 10 \mathrm{H}$, $\mathrm{Ar} \mathrm{H}, \mathrm{Ph} \mathrm{H}$, and $=\mathrm{CH})$; IR (KBr) 2210 and $2205(\mathrm{CN}), 1685$ and $1675(\mathrm{C}=0) \mathrm{cm}^{-1}$; mass spectrum, $m / e 394.962\left(\mathrm{M}^{+}\right.$, calcd for $\mathrm{C}_{19} \mathrm{H}_{10} \mathrm{BrNO}_{2} \mathrm{~S}$ 394.980).

3-Bromo-1,4-dihydro-1,4-dioxo- $\alpha$-1,3-dithian-2-ylidene-2naphthaleneacetonitrile (30): yield $39 \% ; \mathrm{mp} 212-214{ }^{\circ} \mathrm{C}$ (EtOAc/petroleum ether); ${ }^{1} \mathrm{H}$ NMR $\delta$ 8.4-8.0 and 7.95-7.7 (m, $4 \mathrm{H}, \mathrm{Ar} \mathrm{H}), 3.3-2.9\left(\mathrm{~m}, 4 \mathrm{H}, \mathrm{SCH}_{2}\right), 2.45-2.1\left(\mathrm{~m}, 2 \mathrm{H}, \mathrm{CH}_{2}\right) ;{ }^{13} \mathrm{C}$ NMR $\delta 179.0$ and $177.2(\mathrm{~s}, \mathrm{C}=0), 166.7\left(\mathrm{~s},=\mathrm{CS}_{2}\right), 114.4(\mathrm{~s}, \mathrm{CN})$; IR $(\mathrm{KBr}) 2200(\mathrm{CN}), 1680$ and $1665(\mathrm{C}=0) \mathrm{cm}^{-1}$; mass spectrum, $m / e 390.930\left(\mathrm{M}^{+}\right.$, calcd 390.934).

Anal. Calcd for $\mathrm{C}_{16} \mathrm{H}_{10} \mathrm{BrNO}_{2} \mathrm{~S}_{2}\left(M_{\mathrm{r}} 392.293\right)$ : C, 48.99; $\mathrm{H}, 2.57$; $\mathrm{N}, 3.57$. Found: C, $48.76 ; \mathrm{H}, 2.53 ; \mathrm{N}, 3.54$

3-Bromo-1,4-dihydro-1,4-dioxo- $\alpha$-1,3-dithiolan-2-ylidene2-naphthaleneacetonitrile (31): yield $42 \% ; \mathrm{mp} 200-210^{\circ} \mathrm{C}$ dec (toluene); ${ }^{\mathrm{H}} \mathrm{H}$ NMR $\delta 8.25-8.0$ and $7.95-7.7(\mathrm{~m}, 4 \mathrm{H}, \mathrm{Ar} \mathrm{H}), 3.65-3.6$ $\left(\mathrm{m}, 4 \mathrm{H}, \mathrm{SCH}_{2}\right)$; IR $(\mathrm{KBr}) 2200(\mathrm{CN}), 1680(\mathrm{C}=\mathrm{O}) \mathrm{cm}^{-1}$; mass spectrum, $m / e$ 376.921 ( $\mathrm{M}^{+}$, calcd 376.918$)$.

Anal. Calcd for $\mathrm{C}_{15} \mathrm{H}_{8} \mathrm{BrNO}_{2} \mathrm{~S}_{2}\left(M_{\mathrm{r}} 378.266\right)$ : C, 47.63; $\mathrm{H}, 2.13$; $\mathrm{N}, 3.70$. Found: C, $47.60 ; \mathrm{H}, 2.07 ; \mathrm{N}, 3.58$.

General Procedure for the Synthesis of the Amino Quinones 32-35 and 37. To a solution of bromo quinone 28-31 (3.3 $\mathrm{mmol}$ ) in a mixture of benzene and ethanol $(80$ and $10 \mathrm{~mL}$, respectively) was added dropwise a solution of the amine $(8.3$ $\mathrm{mmol}$ ) in benzene $(3 \mathrm{~mL})$ at $0{ }^{\circ} \mathrm{C}$ and stirring was continued for $1 \mathrm{~h}$ at that temperature. Subsequently, EtOAc $(50 \mathrm{~mL})$ was added and the remaining solution was washed with $0.5 \mathrm{~N} \mathrm{HCl}(3 \times 75$ $\mathrm{mL}$ ) and water $(200 \mathrm{~mL})$. After drying with $\mathrm{MgSO}_{4}$ and evaporation of the solvent the crude 32-35 and 37 were obtained and purified as follows: 32 and 37 by flash chromatography (petroleum ether:EtOAc $=3: 1$ ), 33 by chromatography (petroleum ether: EtOAc $=1: 1$ ), and 34 and 35 by recrystallization from EtOAc/ petroleum ether and ethanol, respectively.

$(E / Z)$-1,4-Dihydro-1,4-dioxo- $\alpha$-(phenylmethylene)-3-(1pyrrolidinyl)-2-naphthaleneacetonitrile (32): yield $80 \%$; oil; isomer ratio $=7: 3 ;{ }^{1} \mathrm{H}$ NMR $\delta 8.15-7.25(\mathrm{~m}, 10 \mathrm{H}, \mathrm{Ar} \mathrm{H}, \mathrm{Ph} \mathrm{H}$, and $=\mathrm{CH}$ of the major isomer), $6.99(\mathrm{~s}, 1 \mathrm{H},=\mathrm{CH}), 3.9-3.6[\mathrm{~m}$, $4 \mathrm{H}, \mathrm{NCH}_{2}$ (major isomer)], 3.55-3.25 [m, $4 \mathrm{H}, \mathrm{NCH}_{2}$ (minor isomer)], $2.05-1.8\left(\mathrm{~m}, 4 \mathrm{H}, \mathrm{CH}_{2}\right)$; $\mathrm{IR}(\mathrm{KBr}) 2220(\mathrm{CN}), 1680(\mathrm{C}=\mathrm{O})$

(53) No satisfactory elemental analyses were obtained for this compound, on account of instability. 
Table I. Melting Points, Formation Times, Yields, Characteristic ${ }^{1} \mathrm{H}$ and ${ }^{18} \mathrm{C}$ NMR Spectral Data, and Molecular Ion Values of Compounds $41-46^{\circ}$

\begin{tabular}{|c|c|c|c|c|c|c|c|c|c|c|c|c|c|}
\hline & \multirow{3}{*}{$\begin{array}{l}\operatorname{mp}\left({ }^{\circ} \mathrm{C}\right) \\
\text { (solvent) }\end{array}$} & \multirow{3}{*}{$\begin{array}{c}\text { time, } \\
\text { (h) }\end{array}$} & \multirow{3}{*}{$\begin{array}{c}\text { yield } \\
(\%)\end{array}$} & \multirow{2}{*}{\multicolumn{4}{|c|}{${ }^{1} \mathrm{H}$ NMR $\left(\mathrm{CDCl}_{3}\right), \delta$}} & \multicolumn{4}{|c|}{${ }^{13} \mathrm{C} \mathrm{NMR}\left(\mathrm{CDCl}_{3}\right), \delta$} & \multirow{2}{*}{\multicolumn{2}{|c|}{$\operatorname{MS}\left(\mathrm{M}^{+}\right)$}} \\
\hline & & & & & & & & \multirow[b]{2}{*}{$\mathrm{CN}(\mathrm{s})$} & \multirow[b]{2}{*}{$\mathrm{NCH}(\mathrm{d})$} & \multirow[b]{2}{*}{ C-9/C-11 } & \multirow{2}{*}{$\begin{array}{c}\mathrm{CH}_{2} \mathrm{Ph} / \\
\mathrm{CHS}_{2}\end{array}$} & & \\
\hline & & & & $\overline{\mathrm{CH}_{2} \mathrm{Ph} / \mathrm{CHS}_{2}}$ & $J, \mathrm{~Hz}$ & $\mathrm{NCH}(\mathrm{m})$ & $\mathrm{NCH}_{2}(\mathrm{~m})$ & & & & & found & (calcd) \\
\hline$\overline{41 a^{b}}$ & $151-155(c)$ & $2.45^{d}$ & 58 & 4.02 and 2.95 & 15.0 & $4.5-4.2$ & $4.1-3.2$ & 118.4 & 75.0 & 45.0 & 37.8 & 373.178 & $(373.179)$ \\
\hline $41 b^{b}$ & $151-155(c)$ & $2.45^{d}$ & 29 & $3.9^{e}$ and 3.00 & 13.7 & $4.5-4.2$ & $4.1-3.2$ & 118.4 & 72.5 & 47.5 & 42.1 & 373.178 & $(373.179)$ \\
\hline $42 \mathrm{a}$ & oif & 116 & 85 & 4.10 and 3.13 & 15.2 & $4.3-4.1$ & $3.6-2.9$ & 123.8 & 74.4 & 47.2 & 39.3 & 403.222 & $(403.226)$ \\
\hline $42 b$ & oil $f$ & 116 & 5 & $4.2^{e}$ and 2.78 & 13.4 & $4.3-4.1$ & $3.6-2.9$ & 122.8 & 73.0 & 49.6 & 45.2 & 403.222 & $(403.226)$ \\
\hline 43 & $164-166(c)$ & $3^{g}$ & 70 & 3.86 and 3.10 & 13.9 & $4.14^{h}$ & $3.7-3.5$ & 118.4 & 71.5 & 47.5 & 42.2 & 354.137 & $(354.137)$ \\
\hline $44 a$ & $180-182(i)$ & 3 & 24 & 3.53 and 3.11 & 14.2 & $4.8-4.55$ & $3.9-3.7$ & 117.2 & 67.9 & 48.5 & 41.7 & 368.154 & $(368.152)$ \\
\hline $44 b$ & $214-216(i)$ & 3 & 1 & $3.35-3.0^{j}$ & & $5.1-4.8$ & $3.85-3.65$ & 118.2 & 72.0 & 45.7 & 36.7 & 368.154 & $(368.152)$ \\
\hline 45 & $214-215(i)$ & 240 & 80 & $5.36^{k}$ & & $4.60^{l}$ & $3.85-3.6$ & 116.0 & 70.1 & 52.3 & 52.0 & 382.080 & $(382.081)$ \\
\hline 46 & $232-234(i)$ & 1800 & 70 & $5.91^{k}$ & & $4.41^{m}$ & $3.9-3.5$ & 117.2 & 70.3 & 52.0 & 58.7 & 368.060 & (368.065) \\
\hline
\end{tabular}

${ }^{a}$ All compounds, except $42 \mathrm{a}$ and $42 \mathrm{~b}$, gave satisfactory elemental analyses. ${ }^{b}$ Data concern a mixture of $41 \mathrm{a}$ and $41 \mathrm{~b} .{ }^{c} \mathrm{Diisopropyl}$ ether. ${ }^{d}$ In refluxing toluene $t=8 \mathrm{~h}, 41 \mathrm{a}: 41 \mathrm{~b}=1: 2$, total yield $81 \%$. ${ }^{e}$ This part of the $\mathrm{AB}$ system overlaps with the signals of the $\mathrm{NCH}_{2} \mathrm{moiety}^{\prime}{ }^{\mathrm{B} o t h} 42 \mathrm{a}$ and $42 \mathrm{~b}$ could not be crystallized. ${ }^{g}$ In refluxing toluene $(t=8 \mathrm{~h}) 43$ was obtained in a yield of $33 \% .{ }^{h} \mathrm{t}, J=7.6 \mathrm{~Hz} .{ }^{i}$ EtOAc/petroleum ether. ${ }^{j} \mathrm{~m}$. ${ }^{k} \mathrm{~s}$. ${ }^{l} \mathrm{t}, J=6.6 \mathrm{~Hz},{ }^{m} \mathrm{t}, J=6.8 \mathrm{~Hz}$.

$\mathrm{cm}^{-1}$; mass spectrum, m/e $354.137\left(\mathrm{M}^{+}\right.$, calcd for $\mathrm{C}_{23} \mathrm{H}_{18} \mathrm{~N}_{2} \mathrm{O}_{2}$ 354.137).

$(E)$ - or $(Z)$-1,4-Dihydro-1,4-dioxo- $\alpha$-[(phenylthio)methylene]-3-(1-pyrrolidinyl)-2-naphthaleneacetonitrile (33): yield $71 \%$; mp 176-178 ${ }^{\circ} \mathrm{C}$ (EtOAc/petroleum ether); ${ }^{1} \mathrm{H}$ NMR $\delta$ 8.2-7.9 and 7.8-7.6 (m, $4 \mathrm{H}, \mathrm{Ar} \mathrm{H}), 7.5-7.2(\mathrm{~m}, 5 \mathrm{H}, \mathrm{Ph} \mathrm{H}), 6.96$ $(\mathrm{s}, 1 \mathrm{H},=\mathrm{CH}), 3.7-3.4\left(\mathrm{~m}, 4 \mathrm{H}, \mathrm{NCH}_{2}\right), 2.1-1.75\left(\mathrm{~m}, 4 \mathrm{H}, \mathrm{CH}_{2}\right)$; ${ }^{13} \mathrm{C}$ NMR $\delta 181.8$ and $181.2(\mathrm{~s}, \mathrm{C}=\mathrm{O}), 152.6(\mathrm{~d},=\mathrm{CH}), 119.3(\mathrm{~s}$, CN), $48.1\left(\mathrm{t}, \mathrm{NCH}_{2}\right), 25.2\left(\mathrm{t}, \mathrm{CH}_{2}\right)$; IR (KBr) $2190(\mathrm{CN}), 1660$ $(\mathrm{C}=\mathrm{O}) \mathrm{cm}^{-1}$; mass spectrum, $\mathrm{m} / e 386.106\left(\mathrm{M}^{+}\right.$, calcd 386.109$)$.

Anal. Calcd for $\mathrm{C}_{23} \mathrm{H}_{18} \mathrm{~N}_{2} \mathrm{O}_{2} \mathrm{~S}\left(M_{\mathrm{r}} 386.473\right)$ : C, 71.48; $\mathrm{H}, 4.69$; N, 7.25. Found: C, 71.38; H, 4.69; N, 7.15.

1,4-Dihydro-1,4-dioxo- $\alpha$-1,3-dithian-2-ylidene-3-(1pyrrolidinyl)-2-naphthaleneacetonitrile (34): yield $65 \%$; mp $185-187^{\circ} \mathrm{C}$ (EtOAc/petroleum ether); ${ }^{1} \mathrm{H}$ NMR $\delta 8.2-7.4$ (m, 4 $\mathrm{H}, \mathrm{Ar} \mathrm{H}), 3.9-3.4\left(\mathrm{~m}, 4 \mathrm{H}, \mathrm{NCH}_{2}\right), 3.2-2.8\left(\mathrm{~m}, 4 \mathrm{H}, \mathrm{SCH}_{2}\right), 2.4-1.7$ (m, $\left.4 \mathrm{H}, \mathrm{CH}_{2}\right) ;{ }^{13} \mathrm{C} \mathrm{NMR} \delta 184.2(\mathrm{~s}, \mathrm{C}=0), 156.6\left(\mathrm{~s},=\mathrm{CS}_{2}\right), 117.3$ (s, CN), $53.3\left(\mathrm{t}, \mathrm{NCH}_{2}\right), 29.3$ and $29.0\left(\mathrm{t}, \mathrm{SCH}_{2}\right), 25.6$ and 23.1 (t, $\left.\mathrm{CH}_{2}\right)$; IR ( $\left.\mathrm{KBr}\right) 2200(\mathrm{CN}), 1675(\mathrm{C}=0) \mathrm{cm}^{-1}$; mass spectrum, $m / e 382.078\left(\mathrm{M}^{+}\right.$, calcd 382.081$)$.

Anal. Calcd for $\mathrm{C}_{20} \mathrm{H}_{18} \mathrm{~N}_{2} \mathrm{O}_{2} \mathrm{~S}_{2}\left(M_{\mathrm{r}} 382.504\right): \mathrm{C}, 62.80 ; \mathrm{H}, 4.74$; $\mathrm{N}, 7.32$. Found: $\mathrm{C}, 62.71 ; \mathrm{H}, 4.77 ; \mathrm{N}, 7.25$.

1,4-Dihydro-1,4-dioxo- $\alpha$-1,3-dithiolan-2-ylidene-3-(1pyrrolidinyl)-2-naphthaleneacetonitrile (35): yield $65 \%$; $\mathrm{mp}$ 214-215 ${ }^{\circ} \mathrm{C}$ (ethanol); ${ }^{1} \mathrm{H}$ NMR $\delta 8.15-7.55$ (m, $4 \mathrm{H}, \mathrm{Ar} \mathrm{H}$ ), 3.7-3.4 (m, $8 \mathrm{H}, \mathrm{NCH}_{2}$ and $\left.\mathrm{SCH}_{2}\right), 2.1-1.65\left(\mathrm{~m}, 4 \mathrm{H}, \mathrm{CH}_{2}\right)$; IR (KBr) 2200 $(\mathrm{CN}), 1670(\mathrm{C}=0) \mathrm{cm}^{-1}$; mass spectrum, $m / e 368.065\left(\mathrm{M}^{+}\right.$, calcd 368.065).

Anal. Calcd for $\mathrm{C}_{19} \mathrm{H}_{16} \mathrm{~N}_{2} \mathrm{O}_{2} \mathrm{~S}_{2}\left(M_{\mathrm{r}} 368.477\right)$ : C, 61.93; $\mathrm{H}, 4.38$; $\mathrm{N}, 7.60$. Found: C, $62.08 ; \mathrm{H}, 4.50 ; \mathrm{N}, 7.48$.

$(E / Z)$-1,4-Dihydro-1,4-dioxo- $\alpha$-(phenylmethylene)-3-(1piperidinyl)-2-naphthaleneacetonitrile (37): yield $80 \%$; oil; isomer ratio $=1: 1 ;{ }^{1} \mathrm{H}$ NMR $\delta 8.25-7.0(\mathrm{~m}, 10 \mathrm{H}, \mathrm{Ar} \mathrm{H}, \mathrm{Ph} \mathrm{H}$, and $=\mathrm{CH}), 3.65-3.45$ and $3.4-3.2\left(\mathrm{~m}, 8 \mathrm{H}, \mathrm{NCH}_{2}\right), 2.0-1.2(\mathrm{~m}, 12 \mathrm{H}$, $\left.\mathrm{CH}_{2}\right)$; IR $(\mathrm{KBr}) 2220$ and $2210(\mathrm{CN}), 1680(\mathrm{C}=\mathrm{O}) \mathrm{cm}^{-1}$; mass spectrum, $m / e 368.154\left(\mathrm{M}^{+}\right.$, calcd for $\left.\mathrm{C}_{24} \mathrm{H}_{20} \mathrm{~N}_{2} \mathrm{O}_{2} 368.152\right)$.

( $E, Z)-1,4-D i m e t h o x y-\alpha$-(phenylmethylene)-3-(1pyrrolidinyl)-2-naphthaleneacetonitrile (38) was prepared analogously to 18 and 19 starting from $32(3.54 \mathrm{~g}, 10.0 \mathrm{mmol})$ in a yield of $50 \%$. The major isomer could be isolated as an oil in a yield of $30 \%$ after chromatography $\left(\mathrm{CHCl}_{3}\right)$. Major isomer: ${ }^{1} \mathrm{H}$ NMR $\delta 8.3-7.8$ and 7.7-7.0 (m, 10 H, $\mathrm{Ar} \mathrm{H}, \mathrm{Ph} \mathrm{H}$, and $=\mathrm{CH})$, 3.85 and $3.83\left(\mathrm{~s}, 3 \mathrm{H}, \mathrm{OCH}_{3}\right), 3.6-3.3\left(\mathrm{~m}, 4 \mathrm{H}, \mathrm{NCH}_{2}\right), 2.1-1.9(\mathrm{~m}$, $\left.4 \mathrm{H}, \mathrm{CH}_{2}\right) ;{ }^{13} \mathrm{C}$ NMR $\delta 150.8$ and $148.8(\mathrm{~s}, \mathrm{C}-1$ and $\mathrm{C}-4), 145.4(\mathrm{~d}$, $=\mathrm{CH}), 118.8(\mathrm{~s}, \mathrm{CN}), 62.1$ and $61.9\left(\mathrm{q}, \mathrm{OCH}_{3}\right), 50.7\left(\mathrm{t}, \mathrm{NCH}_{2}\right)$, $26.0\left(\mathrm{t}, \mathrm{CH}_{2}\right)$; IR (KBr) $2210(\mathrm{CN}) \mathrm{cm}^{-1}$; mass spectrum, $\mathrm{m} / e$ $384.180\left(\mathrm{M}^{+}\right.$, calcd for $\left.\mathrm{C}_{25} \mathrm{H}_{24} \mathrm{~N}_{2} \mathrm{O}_{2} 384.182\right)$.

General Procedure for the Synthesis of the 1,4-Bis(acetyloxy)naphthaleneacetonitrile Derivatives 39 and 40 . A mixture of $33,34(0.6 \mathrm{mmol})$, triethylamine $(0.19 \mathrm{~g}, 1.9 \mathrm{mmol})$, zinc powder $(0.05 \mathrm{~g}, 0.8 \mathrm{mmol})$ and acetic anhydride $(2 \mathrm{~mL}, 21.0$ $\mathrm{mmol}$ ) was refluxed for $20 \mathrm{~min}$. After being cooled to room temperature, the reaction mixture was poured into water $(10 \mathrm{~mL})$ and the resulting suspension was extracted with $\mathrm{CH}_{2} \mathrm{Cl}_{2}(3 \times 50$ $\mathrm{mL}$ ). The combined organic layers were washed with water (3 $\times 100 \mathrm{~mL}$ ) and dried with $\mathrm{MgSO}_{4}$. Evaporation of the solvent gave the crude 39 and 40 , which were purified as follows: 39 by flash chromatography $\left(\mathrm{CHCl}_{3}: \mathrm{EtOAc}=25: 1\right)$ and 40 by trituration with diisopropyl ether.

$(E, Z)-1,4-B$ is (acetyloxy)- $\alpha$-[(phenylthio)methylene]-3(1-pyrrolidinyl)-2-naphthaleneacetonitrile (39): yield $41 \%$; isomer ratio $=1: 1 ;{ }^{1} \mathrm{H}$ NMR $\delta 7.9-6.7(\mathrm{~m}, 4 \mathrm{H}, \mathrm{Ar} \mathrm{H}), 7.18$ and $7.17(\mathrm{~s}, 5 \mathrm{H}, \mathrm{Ph} \mathrm{H}), 6.95$ and $6.50(\mathrm{~s}, 1 \mathrm{H},=\mathrm{CH}), 3.5-3.25$ and $3.2-2.8\left(\mathrm{~m}, 4 \mathrm{H}, \mathrm{NCH}_{2}\right), 2.47,2.45,2.42$, and $2.38\left(\mathrm{~s}, 3 \mathrm{H}, \mathrm{CH}_{3}\right)$, 1.9-1.6 (m, $\left.12 \mathrm{H}, \mathrm{CH}_{2}\right)$; IR (KBr) $2240(\mathrm{CN}), 1700(\mathrm{C}=0) \mathrm{cm}^{-1}$; mass spectrum, $m / e 472.142\left(\mathrm{M}^{+}\right.$, calcd for $\left.\mathrm{C}_{27} \mathrm{H}_{24} \mathrm{~N}_{2} \mathrm{O}_{4} \mathrm{~S} 472.146\right)$.

1,4 - $\mathrm{B}$ is (acetyloxy) - $\alpha-1,3$-dithian-2-ylidene-3-(1pyrrolidinyl)-2-naphthaleneacetonitrile (40): yield $43 \%$; $\mathrm{mp}$ $167-168{ }^{\circ} \mathrm{C}$ (EtOAc/petroleum ether); ${ }^{1} \mathrm{H}$ NMR $\delta 7.8-7.6$ and 7.5-7.3 (m, $4 \mathrm{H}, \mathrm{Ar} \mathrm{H}), 3.45-3.25\left(\mathrm{~m}, 4 \mathrm{H}, \mathrm{NCH}_{2}\right), 3.2-2.75(\mathrm{~m}$, $\left.4 \mathrm{H}, \mathrm{SCH}_{2}\right), 2.43\left(\mathrm{~s}, 3 \mathrm{H}, \mathrm{CH}_{3}\right), 2.35-1.8\left(\mathrm{~m}, 4 \mathrm{H}, \mathrm{CH}_{2}\right) ;{ }^{13} \mathrm{C} \mathrm{NMR}$ $\delta 169.1$ and $168.4(\mathrm{~s}, \mathrm{C}=0), 161.6\left(\mathrm{~s},=\mathrm{CS}_{2}\right), 116.5(\mathrm{~s}, \mathrm{CN}), 49.9$ $\left(\mathrm{t}, \mathrm{NCH}_{2}\right), 29.2$ and $29.1\left(\mathrm{t}, \mathrm{SCH}_{2}\right), 26.0$ and $22.9\left(\mathrm{t}, \mathrm{CH}_{2}\right), 20.7$ and $20.5\left(\mathrm{q}, \mathrm{CH}_{3}\right)$; IR $(\mathrm{KBr}) 2200(\mathrm{CN}), 1700(\mathrm{C}=\mathrm{O}) \mathrm{cm}^{-1}$; mass spectrum, $m / e$ 468.109 $\left(\mathrm{M}^{+}\right.$, calcd 468.112).

Anal. Calcd for $\mathrm{C}_{24} \mathrm{H}_{24} \mathrm{~N}_{2} \mathrm{O}_{4} \mathrm{~S}_{2}\left(M_{r} 468.594\right): \mathrm{C}, 61.52 ; \mathrm{H}, 5.16$; N, 5.98. Found: C, 61.71; H, 5.10; N, 5.93.

General Procedure for the Preparation of the Pyrrolo$[1,2-a]$ indoles 41 and 42 , the Benzo[ $f]$ pyrrolo $[1,2-a]$ indoles 43,45 , and 46, and Pyrido[1,2-a ]indole 44. A solution of 15 , $18,32,34,35$, or $37(5.0 \mathrm{mmol})$ in 1-butanol $(50 \mathrm{~mL})$ was heated at reflux temperature. When the reaction was complete as followed from TLC, the solvent was removed under reduced pressure (except in the case of 45). The compounds 41 and 42 were purified by chromatography, using EtOAc (41) and $\mathrm{CHCl}_{3}:$ EtOAc 10:1 (42) as eluents, and the compounds 43 and 44 were purified by flash chromatography, using $\mathrm{CH}_{2} \mathrm{Cl}_{2}: \mathrm{EtOAc}=97: 3(43)$ and $\mathrm{CH}_{2} \mathrm{Cl}_{2}$ (44) as eluents. Compound 41 was obtained as a mixture of cis and trans isomers, which could not be separated. Compound $\mathbf{4 5}$ crystallized upon cooling and was isolated after filtration and trituration with $\mathrm{MeOH}(50 \mathrm{~mL})$. The melting points, formation times, yields, and the characteristic NMR data and molecular ion values of $41-46$ are given in Table $I$.

1-(4-Butoxybutyl)-2,3,4,9-tetrahydro-4,9-dioxo-2-(phenylthio)-1 $H$-benz $[f]$ indole (50). A solution of $33(0.05 \mathrm{~g}, 0.1 \mathrm{mmol})$ in 1-butanol $(2 \mathrm{~mL})$ was heated for $8 \mathrm{~h}$ at $90^{\circ} \mathrm{C}$. After removal of the solvent under reduced pressure the crude residue was subjected to flash chromatography $\left(\mathrm{CHCl}_{3}: \mathrm{EtOAc}=4: 1\right)$ to give 50 as an oil in a yield of $20 \%$ : ${ }^{1} \mathrm{H}$ NMR $\delta 8.2-7.95$ and $7.85-7.6$ (m, $4 \mathrm{H}, \mathrm{Ar} \mathrm{H}), 7.5-7.2(\mathrm{~m}, 5 \mathrm{H}, \mathrm{Ph} \mathrm{H}), 4.8-4.7$ (m, $1 \mathrm{H}, \mathrm{CHCN})$, $3.9-3.75(\mathrm{~m}, 1 \mathrm{H}, \mathrm{NCHS}), 3.7-3.2\left(\mathrm{~m}, 6 \mathrm{H}, 2 \times \mathrm{OCH}_{2}\right.$ and $\left.\mathrm{NCH}_{2}\right)$, 2.25-1.15 (m, $\left.8 \mathrm{H}, \mathrm{CH}_{2}\right), 1.1-0.7\left(\mathrm{~m}, 3 \mathrm{H}, \mathrm{CH}_{3}\right) ;{ }^{13} \mathrm{C} \mathrm{NMR} \delta 179.2$ and $178.4(\mathrm{~s}, \mathrm{C}=\mathrm{O}), 118.6(\mathrm{~s}, \mathrm{CN}), 95.2(\mathrm{~d}, \mathrm{C}-2), 72.0(\mathrm{~d}, \mathrm{C}-3), 67.4$ and $67.3\left(\mathrm{t}, \mathrm{OCH}_{2}\right), 47.2\left(\mathrm{t}, \mathrm{NCH}_{2}\right), 31.6,30.9,22.8$, and $19.3(\mathrm{t}$, $\left.\mathrm{CH}_{2}\right), 13.9\left(\mathrm{q}, \mathrm{CH}_{3}\right) ; \mathrm{IR}(\mathrm{KBr}) 2210(\mathrm{CN}) \mathrm{cm}^{-1}$; mass spectrum, $m / e$ 458.167 $\left(\mathrm{M}^{+}-2\right.$, calcd for $\left.\mathrm{C}_{27} \mathrm{H}_{26} \mathrm{~N}_{2} \mathrm{O}_{3} \mathrm{~S} 458.166\right)$.

$\mathrm{X}$-ray Crystal Structure Determination of 43. Crystals of 43 belong to the monoclinic space group $P 2_{1} / n$, with cell constants $a=11.135$ (3), $b=12.083(6)$, and $c=26.624$ (6) $\AA, \beta=93.76$ $(4)^{\circ}, d_{\mathrm{c}}=1.326 \mathrm{~g} \mathrm{~cm}^{-3}$, and $Z=8$. Intensities were measured with an Enraf-Nonius CAD 4 diffractometer at $293 \mathrm{~K}$ by using graphite-monochromated $\mathrm{Mo} \mathrm{K}_{\alpha}$ radiation $[\omega-2 \theta$ scan mode; scan width $\left.(\omega)(1.2+0.3 \tan \omega)^{\circ} ; 3<\omega<20^{\circ}\right)$. A total of 2174 reflections with $I>3 \sigma(I)$ have been used in the refinement ${ }^{54}$ and 
solution ${ }^{55}$ of the structure. The structure contains two molecules in the asymmetric unit. Both molecules have the same overall conformation but differ somewhat in the orientation of the phenyl group. Hydrogen atoms have been treated as riding atoms with fixed thermal parameters $\left(B=5.0 \AA^{2}\right)$. The remaining atoms have been refined with anisotropic thermal parameters (no. of parameters 380 ). The final $R$ factor was $4.1 \%$.

(54) B. A. Frenz and Associates Inc. (1983), Structure Determination Package, College Station, Texas, and Enraf-Nonius, Delft.

(55) Germain, P.; Main, P.; Woolfson, M. M. Acta Crystallogr., Sect. A 1971, A27, 368 .
Acknowledgment. We are grateful for the financial support of this work by the Netherlands Cancer Foundation and by the Netherlands Foundation for Technical Research (STW), future Technical Science Branch/Division of the Netherlands Organization for the Advancement of Pure Research (ZWO). We also acknowledge J. M. Visser and J. L. M. Vrielink for recording the NMR and T. W. Stevens for recording the mass spectra.

Supplementary Material Available: Lists of positional and thermal parameters, bond lengths, and bond angles ( 8 pages). Ordering information is given on any current masthead page.

\title{
Electroreductive Cyclization. Ketones and Aldehydes Tethered to $\alpha, \beta$-Unsaturated Esters (Nitriles). Fundamental Investigations
}

\author{
R. Daniel Little,* Dennis P. Fox, Luc Van Hijfte, Robert Dannecker, Gregory Sowell, \\ Ronald L. Wolin, Luc Moëns, and Manuel M. Baizer \\ Department of Chemistry, University of California, Santa Barbara, Santa Barbara, California 93106
}

Received August 24, 1987

\begin{abstract}
The intramolecular electrochemically initiated cyclization of a variety of $\alpha, \beta$-unsaturated esters and one nitrile, each of which is tethered to an aldehyde or a ketone, has been investigated. Good yields (70-79\%) of monoand bicyclic products, resulting from closure between the $\beta$-carbon of the $\alpha, \beta$-unsaturated unit and the aldehyde or ketone carbonyl carbon, were obtained. Cyclic voltammetry was used to determine that the $\alpha, \beta$-unsaturated unit corresponded to the electrophore. In all but one instance, cyclization favored formation of the product wherein the hydroxy and (methoxycarbonyl)methyl units were trans to one another. The stereoselectivity was studied as a function of temperature, nature of the proton donor, proton availability, and percent conversion (i.e., as a function of time). Attempts to use the reaction to synthesize the marine natural product ambliol $\mathrm{A}$ were unsuccessful. A mechanistic scheme in which a reversible cyclization of the initially formed radical anion is followed by an irreversible proton transfer is suggested to account for the experimental observations.
\end{abstract}

Introduction. Electroreductive Cyclization (ERC) Reactions. The conjugate addition of lithium sec-butylborohydride to the alkylidenemalonate 1, leading to the formation of the cyclopentyl diester 2 , constitutes one example of what we have previously referred to as a MIRC (Michael-Initiated Ring Closure) reaction. ${ }^{1-4}$ In contrast, an electrochemically initiated reduction of the same substrate afforded the cyclobutyl diester 3 in a reaction involving closure between the $\beta$ (rather than the $\alpha$ ) carbon of the starting material and the bromine-bearing carbon. Once reduced, an umpolung occurs and the formerly electrophilic $\beta$ carbon becomes nucleophilic. In general, MIRC reactions and electroreductive cyclizations complement one another and allow the construction of rings of size $n$ and $n-1$, respectively. ${ }^{5}$

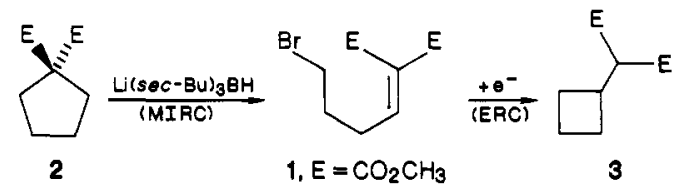

(1) Little, R. D.; Dawson, J. R. Tetrahedron Lett. 1980, 21, 2609 Technically, the term Michael reaction refers to carbon-centered nucleophiles. See: Bergmann, E. D.; Ginsburg, D. Organic Reactions; Wiley: New York, 1959; Vol. 10, Chapter 3.

(2) For a discussion of the development of and application to total synthesis of the tandem Michael-Michael-Ring Closure (MIMIRC) reaction, refer to: Posner, G.; Mallamo, J. P.; Black, A. L. Tetrahedron $1981,37,3921$

(3) Little, R. D.; Dawson, J. R. J. Am. Chem. Soc. 1978, 100, 4607.

(4) Little, R. D.; Verhê, R.; Monte, W. T.; Nugent, S.; Dawson, J. R. J. Org. Chem. 1982, 47, 362.
Aldehydes and Ketones Tethered to $\alpha, \beta$-Unsaturated Esters (Nitriles). Encouraged by these results, we elected to explore use of electroreductive cyclization (ERC) methodology for the construction of a variety of different ring systems and first decided to use substrates wherein a carbonyl unit was tethered to an $\alpha, \beta$-unsaturated ester or nitrile. The successful implementation of the plan would lead to the formation of $\gamma$-hydroxy esters (nitriles) which could, either in situ or in a follow-up step, lead to the production of bi- or tricyclic lactones. ${ }^{6}$

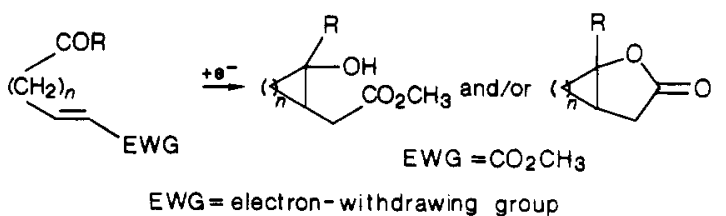

A variety of substrates was examined; the results are illustrated in Table I. In each case, the electroreductive cyclization reactions were carried out at controlled potential in $10 \%$ aqueous acetonitrile with $\mathrm{Et}_{4} \mathrm{NOT}_{\mathrm{s}}$ as the supporting electrolyte. A standard $\mathrm{H}$-cell, a mercury pool cathode, and a saturated calomel reference electrode (SCE) were used; the course of each reaction was monitored as a function of time by coulometry and thin layer chromatography. Each of the examples, except the last, illustrates that the reaction stereoselectively affords products wherein

(5) Nugent, S. T.; Baizer, M. M.; Little, R. D. Tetrahedron Lett. 1982 $23,1339$.

(6) Fox, D. P.; Little, R. D.; Baizer, M. M. J. Org. Chem. 1985, 50, 2202. 